\title{
Archean coastal-plain paleosols and life on land
}

\author{
Gregory J. Retallack, David H. Krinsley \\ Department of Geological Sciences, University of Oregon, Eugene, Oregon, USA 97403 ${ }^{1}$ \\ Robert Fischer, Joshua J. Razink, Kurt A. Langworthy \\ Center for Advanced Materials Characterization, University of Oregon, Eugene, Oregon, \\ USA 97403
}

\begin{abstract}
Coastal-plain paleosols in the 3.0 Ga Farrel Quartzite of Western Australia have organic surface (A horizon) and sulfate-rich subsurface (By) horizons, like soils of the Atacama Desert of Chile, Dry Valleys of Antarctica, and 3.7 Ga paleosols of Mars. Farrel Quartzite paleosols include previously described microfossils, permineralized by silica in a way comparable with the Devonian Rhynie Chert, a well known permineralized Histosol. Five microfossil morphotypes in the Farrel Quartzite include a variety of spheroidal cells (Archaeosphaeroides) as well as distinctive large spindles (new genus provisionally assigned to cf. Eopoikilofusa). Previously published cell-specific carbon isotopic analyses of the Farrel Quartzite microfossils, and unusually abundant sulfate considering a likely anoxic atmosphere, allow interpretation of these morphotypes as a terrestrial community of actinobacteria, purple sulfur bacteria, and methanogenic Archaea.
\end{abstract}

Graphical abstract. (see figure)

\footnotetext{
${ }^{1}$ Tel: 541346 4558: fax 541346 4692. E-mail address: gregr@uoregon.edu
} 
Keywords: Archean, Paleosol, Microfossil, Western Australia

\section{Introduction}

The search for evidence of Archean life on Earth has been unusually successful over the past three decades because of a "basic strategy: look in black (carbon-rich) cherts that are in fine-grained (unmetamorphosed) rocks and associated with Cryptozoonlike stromatolites" (Schopf, 1999). Like stromatolites, the Archean fossil record has been interpreted as marine (Allwood et al., 2006; Flannery and Walter, 2012; House et al., 2013), and rarely lacustrine (Awramik and Bucheim, 2009), although lacustrine is apparently controversial (Sakurai et al., 2005). The variety of putative and likely Archean paleosols are reviewed by Rye and Holland (1998), who assumed that all were sterile to simplify estimates of past atmospheric conditions. Possible microfossils in paleosols have been discounted as remnants of ephemeral ponds (Rye and Holland, 2000). Microbial mats in floodplain and intertidal facies (Homann et al., 2015) also appear more like freshwater aquatic (Flannery and Walter, 2012) than terrestrial crusts (Retallack, 2012). Nevertheless, Archean coastal-plain paleosols may have been hiding in plain sight for several decades as coastal sabkha, playa and salina facies. For example, Buick and 
Dunlop (1990) concluded that 3.5 Ga evaporites were "almost everywhere laid down in a shallow submarine to intermittently exposed environment”. Lowe and Worrell (1999) conclude that 3.4 Ga evaporites "represent sedimentation in marginal hypersaline salinas and low-energy coastal lagoons." These are not only sedimentological facies, but also what soil scientists regard as soils, variously classified as Gypsids (Soil Survey Staff 2014) or Solonchaks (Food and Agriculture Organization, 1974). Playa and salina soils are inundated less commonly than many floodplains, and their development of desiccation cracks, salt crystals, and shear planes are soil-forming rather than sedimentary processes (Retallack, 2001). Evaporitic paleosols of the Farrel Quartzite (3.0 Ga) were also assigned to "shallow to sub-aerial sedimentary environment" by Sugitani et al. (2003). We confirm the discovery by those authors of diagnostic non-marine features and minerals, including sand crystals (Retallack, 2013, 2014; Nabhan et al., 2016), and nahcolite (Lowe and Worrell, 1999; Jagniecki et al., 2015). This study of evaporitic coastal-plain paleosols with preserved microfossils provides geochemical and microfossil evidence for Archean terrestrial microbial communities.

The 3.0 Ga Farrel Quartzite is famous for microfossils of at least five distinct morphotypes (Sugitani et al., 2007, 2009, 2011), validated as genuine microfossils by a variety of isotopic (House et al., 2013), maceration (Grey and Sugitani, 2009), chemical and ultrastructural tests (Oehler et al., 2010). The Farrel Quartzite has been mapped though complex structures (Sugitani et al., 2006), and its hydrothermal and metamorphic history elucidated using whole rock and trace element chemistry (Sugahara et al., 2010). Its sedimentary facies and structures have also been interpreted over an outcrop strike of 
$7 \mathrm{~km}$ (Sugitani et al., 2003). Virtually every aspect of the Farrel Quartzite has been studied except its paleosols.

\section{Materials and methods}

Geological and paleosol sections of the Archean (3.0 Ga) Farrel Quartzite near Mt Grant in the Pilbara region of Western Australia (Fig. 1) were measured and sampled at centimeter scale using a tape measure, and by noting Munsell color and field reaction with dilute hydrochloric acid (Fig. 2). Both color and calcareousness were altered by diagenesis and metamorphism, but these observations are useful for locating the sections. Size, stratigraphic limits, and percentage area occupied by nodules and crystals were also measured in the field. Oriented thin sections prepared vertical to bedding were pointcounted using a Swift automated stage and Hacker counting box. Point counting was adjusted for pervasive silicification and recrystallization to crystallites minimally $5 \mu \mathrm{m}$ across, so that this grain size and smaller was counted as clay. Evaporite minerals were all quartz pseudomorphs, and counted from a distinctive chalcedonic texture unlike simple to undulose extinction of quartz and recrystallized chert. Original evaporite mineralogy could not be determined in thin section, but followed previous identifications based on polished slabs and microprobe analyses of Sugitani et al. (2003). Opaque grains include both kerogen and opaque oxides. Two counts were made from each thin section: one for grain size and one for mineral composition (See Supplementary Information Tables S1 and S2).

Chemical analyses of selected samples (Supplementary Information Table S3) were performed by ALS Chemex of Vancouver, British Columbia, using XRF on glass 
disc and $\mathrm{FeO}$ by Pratt titration. The standard for the analyses was Canadian Certified Reference Materials Project standard SY-4, a diorite gneiss from near Bancroft, Ontario. Errors $(2 \sigma)$ are from 89 replicate analyses of the standard in the same laboratory. This technique failed for analysis of titania, which was below detection $(<0.01 \mathrm{wt} \%)$ for the two samples (R4336 and R4337), but this sample level was analyzed previously in Japan (Sugahara et al., 2010, sample GFSV6) by XRF at $0.0053 \mathrm{wt} \%$. Many chemical compositions were identical to those previously determined for these rocks by Sugitani et al. (2003, 2006), and Sugahara et al. (2010). Cores from the abandoned Mt. Goldsworthy Mines were neither used by their studies nor ours, which are based on the freshest possible samples collected from outcrops.

Bulk densities were determined from 20-40 g samples using paraffin (Retallack, 1997a) at the University of Oregon, with errors from 10 replicate density determinations of Western Australian Archean chert (specimen R4309) in order to calculate gains and losses (mass transfer of Brimhall et al., 1992) of elements in a soil at a given horizon ( $\tau_{\mathrm{w}, \mathrm{j}}$ in moles) from the bulk density of the soil ( $\rho_{\mathrm{w}}$ in g.cm-3) and parent material ( $\rho_{\mathrm{p}}$ in g.cm3) and from the chemical concentration of the element in soils $\left(\mathrm{C}_{\mathrm{j}, \mathrm{w}}\right.$ in weight $\left.\%\right)$ and parent material $\left(\mathrm{C}_{\mathrm{p}, \mathrm{w}}\right.$ in weight $\left.\%\right)$. These data are needed to calculate diagenetic and metamorphic alteration as well as soil formation. Also needed are changes in volume within a single bed during weathering, silicification and metamorphism (strain of Brimhall et al., 1992), estimated from an immobile element in soil (such as Ti used here) compared with parent material ( $\varepsilon_{i, \mathrm{w}}$ as a fraction). Parent material is the rock with sedimentary structures immediately below the profile in which such structures are 
obscured. The relevant equations 1 and 2 (below) are the basis for calculating divergence from parent material composition.

$$
\begin{gathered}
\tau_{j, w}=\left[\frac{\rho_{w} \cdot C_{j, w}}{\rho_{p} \cdot C_{j, p}}\right]\left[\varepsilon_{i, w}+1\right]-1 \\
\varepsilon_{i, w}=\left[\frac{\rho_{p} \cdot C_{j, p}}{\rho_{w} \cdot C_{j, w}}\right]-1 \quad \text { - equation 1 }
\end{gathered}
$$

Quantitative counts of abundance of five recognized morphotypes of microfossils recognized by Sugitani et al. (2011) were made from ten photomicrographs 1300 by 890 $\mu \mathrm{m}$ in size at subdivisions of oriented thin sections. These ten counts were then averaged to obtain numbers of each morphotype per square millimeter. Separate counts were made for microfossils within matrix and enclosed within sand-sized clasts (Supplementary Information Tables S4 and S5). Also counted were spherical pyrite grains and clusters of spherules like framboids of microbial origin (Wignall and Newton, 1998). The fossiliferous thin sections and their source rocks are archived as specimens F118310118312 in the Condon Collection of the Museum of Natural and Cultural History of the University of Oregon.

Microfossils were examined using a transmission electron microscope (Titan 80300 with EDX and EELS), and a scanning electron microscope (FEI Helios Dual Beam, Focused Ion Beam Microscope) in the Center for Advanced Materials Characterization at Oregon (CAMCOR) of the University of Oregon.

\section{Geological setting}


The locality studied at $\mathrm{S} 20.38058^{\circ} \mathrm{E} 119.44567^{\circ}$ is $1.2 \mathrm{~km}$ east of Mt Grant and 2 $\mathrm{km}$ west of Warralong Road, on the crest of the ridge $400 \mathrm{~m}$ north of the vehicular track (Fig. 1). Attention focused on detailed sampling of a short geological section (Fig. 2) corresponding to unit CE2 of fig. 2 of Sugitani et al. (2007) in the uppermost Farrel Quartzite, immediately below conformably overlying shales of the Cleaverville Formation (Fig. 3). The black cherts at this and nearby localities are well known for well preserved microfossils (Sugitani et al., 2006, 2007, 2009).

\section{Geochronology}

A geological age of $3016 \pm 13$ Ma by SHRIMP U-Pb method on zircon has been determined from the youngest population of detrital zircon in Farrel Quartzite beneath Cleaverville Formation at Nunyerry Gap (Nelson, 1998) on the western margin of the East Pilbara Terrane (van Kranendonk, 2010). There is a comparable age of $3058 \pm 7 \mathrm{Ma}$ by the same method from another volcanic sandstone near the base of the Cleaverville Formation on the Cleaverville Peninsula near Karratha in the West Pilbara Block (Nelson, 1998).

The age of the Farrel Quartzite and Cleaverville Formation of the Gorge Creek Group in the eastern Pilbara near the Mt Grant microfossil localities is also bracketed by overlying and underlying rocks (van Kranendonk, 2010). The age of the Lalla Rookh Formation of the unconformably overlying Croydon Group is constrained by a metamorphic age of $2907 \pm 7 \mathrm{Ma}$ by ${ }^{40} \mathrm{Ar} /{ }^{39} \mathrm{Ar}$ on hornblende from the Coolyia Creek Tonalite (Wijbrans and MacDougall, 1987), and intrusion ages of $2936 \pm 5 \mathrm{Ma}$ by U-Pb SHRIMP on zircon of the Keep It Dark Monzogranite (van Kranendonk, 2000), $2927 \pm 3$ 
Ma by U-Pb SHRIMP on zircon of the Woodstock Monzogranite (van Kranendonk, 2010), and $2928 \pm 2 \mathrm{Ma}$ by U-Pb SHRIMP on zircon from the Mulgandinnah Monzogranite (van Kranendonk, 2010). The Gorge Creek Group, which includes the Farrel Quartzite, is younger than the Kangaroo Caves Formation of the upper Sulfur Springs Group, which is dated by U-Pb TIMS-multigrain on zircon as $3240 \pm 2$ Ma from a dacite tuff (van Kranendonk, 2000).

\section{Sedimentary paleoenvironments}

Paleoenvironments of the microfossil locality near Mt Grant have been interpreted by sedimentary facies analysis as fluvial and coastal plain (Sugitani et al., 2006, 2007). The base of the Farrel Quartzite is trough cross-bedded sandstone and conglomerates filling paleovalleys of the Sunrise Hill angular unconformity with the Kelly and Warrawoona Groups (Dawes et al., 1985). Evaporite sand crystals of nahcolite and barite, now pseudomorphed by silica, have been identified from microprobe analyses and crystallographic studies, and interpreted as evaporites of coastal salinas (Sugitani et al., 2003). The overlying Cleaverville Formation of laminated shale and banded iron formation is interbedded with pillow basalts of a volcanic island arc near Karratha in the western Pilbara craton (Shibuya et al., 2007), and includes submarine fan facies turbidites in the southern Pilbara block (Eriksson, 1982; Eriksson et al., 1994). The East Pilbara lower Cleaverville Formation and underlying Farrel Quartzite, however, share slightly suprachondritic Y/Ho ratios and slight europium anomalies, characteristic of freshwater, and distinct from modern open ocean values and the marine stromatolitic, 3.4 Ga, Strelley Pool Chert (Sugahara et al., 2010). Two of the seventeen Farrel Quartzite cherts analyzed 
by Sugahara et al. (2010) have high europium anomalies indicative of local hydrothermal springs). Hydrothermal sources may also explain anomalously low $\mathrm{Al}_{2} \mathrm{O}_{3} / \mathrm{TiO}_{2}$ ratios in a few samples of the Farrel Quartzite (Sugitani et al., 2006). A lacustrine lower Cleaverville Formation near Mt Grant is also compatible with its proposed tectonic setting within a backarc basin (Eriksson, 1982) or intracontinental sag (Van Kranendonk et al., 2007).

The source terrane of the Farrel Quartzite included felsic and andesitic volcanics, as well as tonalites, trondhjemites and granite, judging from Th-Sc-La values (Sugitani et al., 2006) and from zircons in the Farrel Quartzite as old as $3.71 \pm 0.16$ to $3.67 \pm 0.16 \mathrm{Ga}$ (Sugitani et al., 2006). These deposits of a shallow sea or lake (Cleaverville Formation) and coastal plain (Farrel Quartzite) accumulated on a protocontinent created by the Prinsep Orogeny, which amalgamated the Karratha and East Pilbara crustal blocks into a landmass about $500 \mathrm{~km}$ across (van Kranendonk et al., 2007, 2010). The Kaapvaal craton, some $1000 \mathrm{~km}$ across, may have been an additional contiguous landmass judging from alignment of greenstone belts, although paleomagnetic evidence for this Vaalbara supercontinent is only documented by $2.7 \mathrm{Ga}$ (de Kock et al., 2009).

The bedrock landscape represented by the Sunrise Hill unconformity beneath the Farrel Quartzite (Dawes et al., 1985), had as much as $1 \mathrm{~km}$ of relief, judging from local differences in thickness in the fluvial-coastal Farrel Quartzite (Sugitani et al., 2003; van Kranendonk et al., 2006). A continental calcalkaline volcanic arc on the southern and western edge of the Karratha-East Pilbara Craton was envisaged by Eriksson (1982), comparable with the Cascades volcanic arc of Oregon (McCaffrey et al., 2013). In 
contrast, Van Kranendonk et al. (2007) did not recognize arc volcanics and proposed that the basin of the Farrel Quartzite was opened by intracontinental subsidence.

\section{Metamorphic-diagenetic alteration}

The Farrel Quartzite is folded and faulted, along with older basement rocks, into near-vertical dips and isoclinal folds typical of many Archean greenstone belts (Fig. 1). Like many outcrops in this region, they are metamorphosed to lower greenschist facies, as indicated by metamorphic sericite, chlorite, epidote and apatite (Sugitani et al., 2003). The Cleaverville Formation in the western Pilbara near Karratha shows three distinct phases of metamorphism not observed in Cleaverville Formation in the East Pilbara region near Mt Grant (Kiyokawa et al., 2002; Hickman, 2004; Shibuya et al., 2007). The Farrel Quartzite and Cleaverville Formation also escaped contact metamorphism of the Warrawoona and Kelly Groups during emplacement of the Carlindi Granitic Complex about $6 \mathrm{~km}$ to the south (Smithies, 2004), mostly 3490-3225 Ma, but with minor intrusions 2955-2830 Ma in age (van Kranendonk, 2010). Microfossil-bearing cherts near Mt Grant are less veined and microfaulted than cherts of the Warrawoona and Kelly Groups. There is also evidence for less severe hydrothermal alteration of cherts in the Farrel Quartzite from lack of MREE enrichment or pronounced europium anomalies (Sugahara et al., 2010).

Another measure for post-depositional alteration is burial depth, which for microfossil localities near Mt Grant was not as high as for other areas of the Farrel Quartzite, because the studied outcrops were on a paleotopographic high between the Archean Mallina Basin to the west and the Paleozoic-Mesozoic Canning Basin to the east 
(Smithies, 2004). The Gorge Creek Group is up to 1900 m thick (van Kranendonk, 2010) south of the former shelf edge (Eriksson, 1982). The Cleaverville Formation near Mt Grant was no more than 1000 m thick (van Kranendonk et al., 2006). The Farrel Quartzite can reach $1000 \mathrm{~m}$ thick to the west, but is only $80 \mathrm{~m}$ thick at the investigated microfossil localities (Sugitani et al., 2003). The Lalla Rookh Formation of the overlying Croydon Group was confined to fault basins to the south (Krapež, 1984), and its $3000 \mathrm{~m}$ did not overlie the microfossil localities, which were covered by Constantine Sandstone of the Croydon Group no thicker than $1300 \mathrm{~m}$, and a comparable thickness of Mallina Formation (van Kranendonk, 2010). The Fortescue Group in the vicinity of Mt Grant is represented by metagabbro intrusions (Smithies, 2004), and these widespread lavas and sediments covered this area to a thickness of at least $620 \mathrm{~m}$ as in Balfour Downs to the east (Thorne and Trendall, 2001). Mesozoic and Cenozoic overburden in the Canning Basin revealed by nearby Chirup Well (Lipski, 1994) reached no more than $900 \mathrm{~m}$. Thus the microfossil localities near Mt Grant may have been buried by at least $4.8 \mathrm{~km}$ of overburden, which amounts to about $1.3 \mathrm{kbar}$ or $0.1 \mathrm{GPa}$ pressure in typical continental crust (Thompson, 1992) as envisaged by Van Kranendonk et al. (2007), and would reach greenschist facies only at an elevated geothermal gradient of a backarc basin envisaged by Eriksson (1982).

At such depths of burial enrichment in potassium (smectite illitization) is common (Nesbitt and Young, 1989; Fedo et al., 1995; Novoselov and de Souza Filho, 2015), although illitization is promoted at room temperature and pressure by the dissimilatory metal-reducing bacterium Shewanella (Kim et al., 2004). The ternary diagram of Nesbitt and Young (1989) shows weathering trends in mineralogically mature paleosols but no 
clear illitization (Fig. 4A). Potash enrichment is apparent from mass transfer with respect to aluminum (Fig. 4B), but is modest compared with other Precambrian paleosols enriched in potassium by as much as 8-12 moles (Novoselov and de Souza Filho, 2015). Two samples (R4336 and R4337) were markedly enriched in silica, but without consistent enrichment of alkalies and alkaline earths (Fig. 4B-F). The other samples did not show such off-scale silicification, which must have occurred during or soon after burial to preserve the microfossils so beautifully (Sugitani et al., 2007, 2011). These paleosols may have been protected from extensive diagenetic and metamorphic chemical alteration by early silicification.

\section{Criteria for microfossil biogenicity}

Putative Archean microfossils from the very same beds of the Farrel Quartzite sampled here (Fig. 5) passed a variety of critical tests for biogenicity by Sugitani et al. (2007, 2009, 2011, 2013). The microfossils are common in both clasts and matrix of silicified sediments (Sugitani et al., 2007, 2011). Abundant microfossils show a limited range of similar morphologies in petrographic thin section (Sugitani et al., 2011), are extractable by palynological techniques (Grey and Sugitani, 2009), and have individually distinct

$\delta^{13} \mathrm{C}$ compositions (House et al., 2013), $\mathrm{C} / \mathrm{CN}$ ratios and $\mathrm{S}$ concentrations (Oehler et al., 2010). Our additional observations support their interpretation as microfossils and shed light on mechanisms of preservation.

\subsection{Taphonomic series}


A key test of biogenicity for Precambrian fossils is an array of preservation (Hofmann, 2004) from well preserved to partly decayed. The best microfossil preservation in the rocks studied was seen at the top of the bed at $1.8 \mathrm{~m}$ in the measured section of Fig.3, but quality of preservation and abundance of microfossils decreaseddownward within that bed. The other two beds sampled intensively also showed this relationship of preservation better toward at the top of the bed, but also more abundant framboids toward the base of the bed (Fig.6).

\subsection{Late diagenetic chert neomorphism}

Examination of the microfossils under the scanning electron microscope and transmission electron microscope (Fig. 7) demonstrates that cell lumens have been infiltrated by silica in the same way as permineralized wood (Retallack, 2011). The cell walls have been partly broken by recrystallization of silica revealed as domains of uniform grey tone in back-scatter scanning electron microscopy (Fig. 7A-B). These neomorphic domains about 2-5 $\mu \mathrm{m}$ across are apparent as a pixelated effect when examined under a crossed polarizers in a petrographic microscope (Fig. 8A), compared with plane light (Fig. 8B). Such recrystallization can give the misimpression of reticulate and spinose walls, widely recognized in permineralized microfossils (Sergeev et al., 2012). Under transmission electron microscopy, however, the cell walls can be traced across neomorphic crystal boundaries (Fig. 7D). Thus, these fossils are not entirely artefacts of organic matter displacement by crystal growth, as suspected for other microfossils (Brasier et al., 2015). 


\subsection{Organic matter maturity}

Under the high-resolution transmission electron microscope, the organic matter is degraded into ropes $1 \mathrm{~nm}$ wide, distinct from particulate organic matter in the cherty matrix (Fig. 7D). Ropes of this size are comparable in diameter with 15 fused aromatic rings, and distinct from crystalline graphite (Derenne et al., 2008).

\subsection{Mechanisms of permineralization}

Preservation of the Mt Grant microfossils is comparable with permineralization of fossil plants in the Rhynie Chert of the Early Devonian, Old Red Sandstone, Scotland (Rice et al., 1995), as confirmed by comparison with thin sections of Rhynie Chert (Condon Collection Museum of Natural and Cultural History F10670, 107011, 108385). The Rhynie Chert has been interpreted as a sequence of marsh paleosols at the margins of a volcanic hot spring (Rice et al., 1995). The precursor Devonian peats of the Rhynie Chert can be classified in various soil classifications as Fibrists (Soil Survey Staff, 2014), Dystric Histosols (Food and Agriculture Organization, 1974), and Fibric Organosols (Isbell, 1996). From a geological perspective, the Rhynie chert was a sintered peat, in which cellular permineralization was favored by siliceous hot waters and by exclusion of decomposers and oxygen under waterlogged conditions (Rice et al., 1995). Microbial silicification is also apparent in modern hot springs, but occurs in laminated sinters, unlike the Rhynie Chert and Farrel Quartzite (Konhauser et al., 2001; Kyle et al., 2007). Both Farrel and Rhynie cherts are black with structured organic matter, neomorphically recrystallized, and cut by narrow quartz veins (Fig. 8A-B). In both cases, massive fossiliferous chert is distinct from interbedded, laminated, shale and sandstone (Fig. 9). 
Independent evidence for local hot spring activity during accumulation of the Farrel Quartzite comes from two samples with unusually low $\mathrm{Al}_{2} \mathrm{O}_{3} / \mathrm{TiO}_{2}$ ratios (Sugitani et al., 2006) and unusually high europium anomalies (Sugahara et al., 2010). Comparable silica enrichment of the surface horizon of the bed at $1.8 \mathrm{~m}$ in Fig. 3 is especially suggested by its extremely low titania and alumina (Supplementary Information Table S3), so that clastic input was overwhelmed by silica enrichment. (Fig, 4C-F).

Differences are also instructive, especially the abundance and variety of early diagenetic evaporite pseudomorphs (Sugitani et al., 2003) in the Mt Grant cherts (Fig. 10), which are absent from Rhynie Chert. Thus, silicifcation of Farrel Quartzite also may be related to formation of playa cherts (Hay, 1968; Eugster, 1969) A combination of volcanic glass precursors, very high $\mathrm{pH}(>9)$, and silica-accumulating microbes mobilize silica gels in playa lakes (Eugster, 1969; Larsen, 2008). Sulfate-reducing bacteria, evident from framboids in the Farrel Quartzite paleosols (Fig. 5F-H), excrete silica spicules and are capable of silicification of evaporites (Birnbaum and Wireman, 1985; Birnbaum et al., 1989). In addition, microorganisms can be preserved in flocculant organic oozes, which persist by desiccation and salt-pickling in dry soda lakes for later permineralization (Birnbaum et al., 1989). Microfossiliferous cherts (Fig. 8A-B) can be contrasted with silicified sediments poor in microfossils (Fig. 8C-E). The playa chert model for silicification is appealing for many fossiliferous Precambrian intertidal cherts (Maliva et al., 2005), and is especially plausible for beds of the Farrel Quartzite with evaporite pseudomorphs (Sugitani et al., 2003).

Thus two mechanisms are envisaged for the fine preservation of microfossils near hot springs and indifferent preservation of microfossils in coastal salinas. 
Microfossiliferous cherts are evidence of silicification before cells could decay, which takes about 160 days for cyanobacteria under anoxic conditions (Harvey et al., 1995). In contrast to these fossiliferous black cherts, unfossiliferous sedimentary rocks and the lower parts of paleosols may have been silicified by a third mechanism, namely diagenetic and metamorphic silica released from pressure solution, deep groundwaters, and clay diagenesis (Siever, 1962).

\section{Criteria for recognizing paleosols}

Microfossils of the Farrel Quartzite have been considered marine (House et al., 2013), but their matrix lacks lamination, stromatolites, or soft-sediment deformation (Fig. 9) found in Archean lacustrine and marine rocks (Allwood et al., 2006; Flannery and Walter, 2012). Prior facies analysis (Sugitani et al., 2007), concluded that the Farrel Quartzite was deposited in fluvial to coastal-plain paleoenvironments. Furthermore, the terrestrial playa mineral nahcolite $\left(\mathrm{Na}_{2} \mathrm{CO}_{3}\right)$ has been recognized from crystal pseudomorphs of the Farrel Quartzite (Sugutani et al. 2003).

\subsection{Field appearance}

A first test of the paleosol hypothesis is field observations of sharp tops and gradational changes downward like a soil profile, and a variety of disruptions that obscure bedding and ripple marks of lower layers like soil structure. Especially soil-like structures are near-vertical cracks joining a system of subhorizontal cracks (cutans), and generally massive unlaminated structure (especially evident in thin sections cut vertical to bedding: Fig. 8A-B). 
Also diagnostic of paleosols are nodularized and etched pseudomorphs of evaporite minerals with clayey seams and many included grains like pedogenic sand crystals (Fig. 10D), comparable with those widespread in Precambrian paleosols (Retallack, 2013; Nabhan et al., 2016). Replacive evaporite sand crystals are characteristic of aridland soils, whereas marine and lacustrine evaporite crystals are clean of inclusions and displacive (Campbell and Claridge, 1987; Amundson et al., 2012; Retallack, 2012, 2014). Familiar examples of non-marine sand crystals are the "barite roses" of Oklahoma (London, 2008), which can be contrasted with transparent marine gypsum in "chrysanthemum stones" of China (Zhao et al., 1998). The large (5-20 mm) sand crystal pseudomorphs of the Farrel Quartzite are scattered within particular beds, unlike hydrothermal barite or nahcolite, which is confined to veins and microinclusions (Samson et al., 1995; Kamenetsky et al., 2002; Rye, 2005).

Finally, black cherty beds suspected to be paleosols were traceable over $7 \mathrm{~km}$ laterally (Sugitani et al., 2007), like soils of an extensive coastal plain (Retallack, 1997, 2013).

\subsection{Mineral variation within beds}

A second test of the paleosol hypothesis was to quantify mineral composition of the beds by petrographic point-counting to see if there was a loss of weatherable minerals upwards within individual profiles. These counts assumed $5 \mu \mathrm{m}$ neomorphic recrystallization of permineralizing silica documented by transmission electron microscopy (Fig. 7D). There is marked fragmentation and embayment of rock-fragment grains upwards in the profile, as well as a decline in abundance of silicified feldspar, 
coordinated with increases in clay rims and matrix (Fig. 6). This pattern is compatible with hydrolytic weathering reactions within a paleosol (Amundson et al., 2012; Retallack, 2012, 2014).

\subsection{Geochemical mass balance}

A third test for paleosols was to analyze chemical data within a framework of chemical mass balance, or "tau analysis", to see if within-bed changes fall within the collapse-and-loss quadrant of soils or the dilate-and-gain quadrant of sedimentation (Fig. 11), cementation, silicification, illitization, or ore mineralization (Fig. 4). This analysis normalizes to a stable constituent in parent material (titanium was used in this case), and calculates mole fractions from weight percent and bulk density of each sample using equations 1 and 2 (Brimhall et al., 1992). Most sampled beds qualified as paleosols, with the exception of two specimens of the bed at $1.8 \mathrm{~m}$ showing off-scale additions (Fig. 4C$\mathrm{F}, 11)$. This anomaly in the surface of the bed at $1.8 \mathrm{~m}$ is also seen in molecular weathering ratios of alumina/bases (Fig. 6). These geochemical differences are too large to be explained by sediment addition, and are best explained by silicification of a sediment-poor, organic surface horizon . Tau analysis also reveals a marked depletion of phosphorus in one of the profiles, with modest change in the other two (Fig, 11). Phosphorus requires organic ligands, and thus biological activity for mobilization (Neaman et al., 2005). Furthermore, the degree of phosphorus depletion is proportional to the degree of soil development judged by destruction of sedimentary structures and size of nodules (Fig. 10D). Phosphorus depletion in the least baritic profiles is most 
instructive, because barite requires $\mathrm{pH}$ low enough to leach phosphorus abiotically (Neaman et al., 2005; Jennings et al., 2015).

\subsection{Microfossil distribution within beds}

A fourth test of the paleosol hypothesis is the distribution of microfossils, which would be evenly distributed if they lived in accreting microbial mats, but show pronounced horizonation (Fig.6), as in paleosols (Retallack, 2012). Even in the silicified upper part of the bed at $1.8 \mathrm{~m}$ in Fig. 2 they are not aligned between microbial mat laminae (Fig. 5A-C), and in other parts of the profiles they are intergranular (Fig. 5D-E) or entirely within dislodged soil peds or grains (Fig. 5F-H).

Five distinct microfossil morphotypes of carbonaceous microfossils have been recognized by Sugitani et al. (2011) and mostly characterized isotopically (House et al., 2013). These morphotypes (Fig. 5A-E) as well as opaque pyrite framboids (Fig. 5F-H) as possible traces of the activity of sulfur reducing microbes, were counted from photomicrographs of known area to determine abundance of each microfossil morphotype (number.mm ${ }^{-2}$ ). Microfossils in matrix were counted separately from those entirely within clasts, because of erosion and redeposition of fossiliferous clasts (Sugitani et al., 2007). Microfossils within clasts and clasts are erratic in their distribution within beds, but microfossils in matrix show much greater abundance at the surface of beds (just below 0 levels in Fig. 6), as expected for microbial earth paleosols (Retallack, 2012).

\section{Interpreted paleoenvironments of the paleosols}


Each kind of paleosol (Table 1) in the Farrel Quartzite, recognized from the evidence outlined above, offers paleoenvironmental information (Table 2). This is justified in the following paragraphs to generate a coherent model for their paleoenvironment (Fig. 12). Non-genetic pedotype names are from the East Pilbara aboriginal language Nyamal (Burgman, 2007), combined with an equally non-genetic textural term to specify a particular paleosol. The following paragraphs follow the five classical soil forming factors (Retallack, 2001), as well as atmospheric $\mathrm{CO}_{2}$ and $\mathrm{O}_{2}$.

\subsection{Parent material}

Paleosols of the Farrel Quartzite are developed on quartzofeldspathic sand with small amounts of clay and rock fragments (Fig. 6), including volcanics, schist and chert. These clasts are evidence of provenance from continental volcanic arc of felsic and andesitic volcanics, and older continental terranes with chert, metamorphic rocks, tonalites, trondhjemites, and large expanses of granite. These petrographic observations of Sugitani et al (2006) are also supported by their analysis of Th-Sc-La values. In this backarc-intracontinental geological setting (Eriksson, 1982; Van Kranendonk et al., 2007), lack of first-cycle volcanic fragments in the form of shards, scoria and pumice is surprising, but devitrification of volcanic glasses may have contributed to the pervasive silicification and neomorphism of the Farrel Quartzite. Detrital zircons dated at $3016 \pm 13$ and $3058 \pm 7$ by SHRIMP U-Pb agree with the interpolated geological age of the Farrel Quartzite (Nelson, 1998), and are evidence of active felsic volcanism.

\subsection{Topographic setting.}


The sedimentary setting of the Farrel Quartzite was a coastal plain (Sugitani et al., 2006, 2007), perhaps beside a lake with later marine influence, now represented by the Cleaverville Formation (Sugahara et al., 2010). There may have been as much as $1 \mathrm{~km}$ of relief in hinterlands (Dawes et al., 1995; van Kranendonk et al., 2006), but the paleosols developed on flat landforms, as demonstrated by the Kari pedotype, which is traceable for $7 \mathrm{~km}$ along strike (Sugitani et al., 2003).

Permanent water table in this floodplain was at least $25 \mathrm{~cm}$ below the surface of the paleosols because above that level evaporite sand crystals and nodules show replacive growth, which is characteristic of soils (Retallack, 2012), as revealed by common sedimentary inclusions (Fig. 8C-D, 10D-E), zones of dissolution (Fig. 10D-E), dusty rims (Fig. 10C), and undeformed bedding planes (Fig. 10E), as in playa lakes (Hay, 1968; Renaut and Tiercelin, 1994) . In contrast, evaporite crystals precipitated from open water or saturated sediments are free of inclusions because they grow displacively: such crystals are well known from marine evaporates (Warren, 2006; Ziegenbalg et al., 2010), and spring tufas (Donovan et al., 1988; Bonny and Jones, 2008a-b). Barites that formed below water table in sulfur springs also differ from those of the Farrel Quartzite in being aligned with original bedding (Donovan et al., 1988; Bonny and Jones, 2008a-b). Hot spring water is discernible in the surface horizon of the Jurnpa paleosol from its off-scale silica enrichment tau value (Fig. 11) and large europium anomalies (Sugahara et al., 2010). However, these geochemical proxies for hot spring proxies are found only in the two upper samples of that paleosol, and not in the other paleosols. Floodplains of the Farrel Quartzite may have been dotted with spring mounds and artesian blisters (Fig. 12), like those on the shore of Lake Bogoria, Kenya (Ashley et al., 2002; Owen et al., 2008). 
Barite spring mounds and their feeder dikes have not yet been found in the Farrel Quartzite, but are documented for the 3.5 Ga Dresser Formation of Western Australia (van Kranendonk and Pirajno, 2004; van Kranendonk et al., 2008).

\subsection{Time for soil development.}

Paleosols of the Farrel Quartzite range from moderately developed for the Jurl and Kari pedotypes to weakly developed for the Jurnpa pedotype and very weakly developed for the Ngumpu pedotype, in a field scale devised for modern soils (Retallack, 2001). A critical field observation is the relative destruction of bedding, which is difficult to trace in moderately developed paleosols because laminations and cross bedding have been disrupted by soil cracking and settling (Fig. 3C-D). These field observations have been confirmed by thin sections cut perpendicular to bedding to show massive fabrics in the paleosols (Fig. 9A-B), compared with laminated fabrics above and below (Fig. 9D-E), and mixed massive-bedded fabrics in between (Fig. 9C).

A more important index of soil development is the formation of discrete nodules or sand crystals, which define moderate development, and take many millenia to form in modern soils (Retallack, 2001). For example, low magnesium calcite nodules in radiocarbon-dated soils of New Mexico grow in diameter $(S$ in $\mathrm{cm})$ with soil age $(A$ in kyrs) according to the following equation (Retallack, 2005, $\mathrm{R}^{2}=0.57$; S.E. $\pm 1.8 \mathrm{kyrs}$ ).

$$
A=3.92 S^{0.34} \quad \text { - equation } 3
$$

Gypsum sand crystals in the Negev and Atacama Deserts increase in abundance ( $G$ in area \%) with soil age ( $A$ in $\mathrm{k} . \mathrm{yrs})$ according to another equation (Retallack, 2013, $\mathrm{R}^{2}=$ 0.95, S.E. \pm 15 kyrs). 


$$
A=3.987 G+5.774 \quad \text { - equation } 4
$$

If the sand crystals and nodules of Farrel Quartzite paleosols were calcite and had original diameters as now measured in the field (Fig. 2), equation 3 would yield 3.6. \pm 1.8 kyrs for Jurl, $7.9 \pm 1.8$ kyrs for upper Kari, $8.3 \pm 1.8$ kyrs for lower Kari, and 3.3 \pm 1.8 kyrs for Jurnpa paleosols. If the crystals and nodules were gypsum in volume percent averaged from point counting (Fig. 10), equation 4 would yield $67.2 \pm 15$ kyrs for Jurl, $101.5 \pm 15$ kyrs for upper Kari, $80.7 \pm 15$ kyrs for lower Kari, and $44.0 \pm 15$ kyrs for Jurnpa paleosols. These estimates are orders of magnitude different, but provide broad constraints. They are not strictly relevant because pedogenic nodules and crystals in Farrel Quartzite are silica pseudomorphs of barite and nahcolite (Sugitani et al., 2003). Because nahcolite requires much higher than modern $\mathrm{CO}_{2}$ partial pressures (Eugster, 1966; Jagniecki et al., 2015) and barite nodules require anoxic sulfur bacterial biomineralizers (Jennings et al., 2015), there is little hope for obtaining chronofunctions for formation of either mineral from Holocene soils (Retallack and Kirby, 2007; Jennings et al., 2015). Although quantitative estimates for duration of soil formation in the Archean remain elusive, many millenia were needed for Jurl, Kari and Jurnpa paleosols, and proportionally less for Ngumpu paleosols.

\subsection{Paleoclimate}

Most pedogenic paleothermometers are based on modern forest to desert shrubland soils (Sheldon et al., 2002; Gallagher \& Sheldon, 2013), but a pedogenic paleothermometer based on modern soils under tundra of Iceland (Óskarsson et al., 2012) is more appropriate for Archean paleosols. This linear regression between mean annual 
temperature $\left(\mathrm{T}\right.$ in $\left.{ }^{\circ} \mathrm{C}\right)$ and chemical index of weathering $\left(\mathrm{I}=100 \mathrm{mAl}_{2} \mathrm{O}_{3} /\left(\mathrm{mAl}_{2} \mathrm{O}_{3}+\right.\right.$ $\left.\mathrm{mCaO}+\mathrm{mNa}_{2} \mathrm{O}\right)$, in molar proportions is given in equation $3\left(\mathrm{R}^{2}=0.81\right.$; S.E. $\left.= \pm 0.4^{\circ} \mathrm{C}\right)$

$$
T=0.21 I-8.93 \quad-\text { equation } 5
$$

These calculations yield temperate mean annual paleotemperatures for the lower A horizons of Jurl $\left(11.1 \pm 0.4^{\circ} \mathrm{C}\right)$, Jurnpa $\left(8.3 \pm 0.4^{\circ} \mathrm{C}\right)$ and Kari $\left(10.1 \pm 0.4^{\circ} \mathrm{C}\right)$ paleosols of the Farrel Quartzite.

These results are comparable with application of this paleothermometer to the thick (6 m) Jericho Dam paleosol below the 3.0 Ga Pongola Supergroup in South Africa (Grandstaff et al., 1986), which may have been within the same paleoclimatic belt as the 3.0 Ga Farrel Quartzite (de Kock et al., 2009). The Jericho Dam sample at $1.7 \mathrm{~m}$ depth yielded mean annual temperature of $11.1 \pm 0.4^{\circ} \mathrm{C}$ for chemical index of weathering (Óskarsson et al., 2012). These results are also consistent with "temperate paleoclimate" $\left(<40^{\circ} \mathrm{C}\right)$ inferred for the $3.4 \mathrm{Ga}$ Buck Reef Chert of South Africa, using combined oxygen and hydrogen isotopic evidence (Hren et al., 2009), and revising earlier estimates of 55$85^{\circ} \mathrm{C}$ from oxygen isotopic evidence throughout the Archean (Knauth and Lowe, 2003). Temperatures less than $75^{\circ} \mathrm{C}$ are also indicated by $16-36$ volume $\%$ original quartz in the Farrel Quartzite (Fig. 6), because quartz would be prone to dissolution at higher temperature and $\mathrm{pH}$ (Sleep and Hessler, 2006). This line of inference is inappropriate for little-weathered sediment of tectonically active terranes (Lowe, 2007), but facies and grain size of the Farrel Quartzite are evidence of subdued tectonic activity (Eriksson, 1982; Sugitani et al., 2003, 2006).

A widely used paleohyetometer (Sheldon et al., 2002) based on temperate soils of North America uses chemical index of alteration without potash $(R=$ 
$100 \mathrm{mAl}_{2} \mathrm{O}_{3} /\left(\mathrm{mAl}_{2} \mathrm{O}_{3}+\mathrm{mCaO}+\mathrm{mNa}_{2} \mathrm{O}\right)$ in moles$)$, which increases with mean annual precipitation $(P$ in $\mathrm{mm})$ in modern soils $\left(\mathrm{R}_{2}=0.72\right.$; S.E. $\left.= \pm 182 \mathrm{~mm}\right)$, as follows.

$$
P=221 \mathrm{e}^{0.0197 R} \quad \text { - equation } 6
$$

Equation 6 is based on the hydrolysis equation of weathering, which enriches alumina at the expense of lime, magnesia, potash and soda. Magnesia is ignored because it is insignificant for most clastic sedimentary rocks (Maynard, 1992), and potash is excluded because it can be enriched during deep burial alteration of sediments (Novoselov and de Souza Filho, 2015). This paleohyetometer is not effective for little-weathered gypsic soils, but works for modern baritic soils and paleosols because they are deeply weathered (Jennings and Driese, 2014; Jennings et al., 2015). This chemical index of alteration paleohyetometer yields humid mean annual precipitation for lower A horizons of Jurl (1443 $\mathrm{mm} \pm 182)$, Jurnpa (1112 \pm 182$)$ and Kari $(1319 \mathrm{~mm} \pm 182)$ paleosols of the Farrel Quartzite.

These data support other indications of deep weathering such as light rare earth enrichment of the Farrel Quartzite and its cherts (Sugahara et al., 2010). The $3.0 \mathrm{Ga}$ Jericho Dam paleosol of South Africa is also deeply weathered $(6 \mathrm{~m})$ and indicative of a humid climate (Grandstaff et al., 1986): mean annual precipitation of $1452 \mathrm{~mm}$ can be calculated from a sample at $1.7 \mathrm{~m}$ using the chemical index of alteration without potash equation (Sheldon et al., 2002).

Evaporites, such as gypsum, which is widespread in desert soils (Retallack and Huang, 2010) are potential evidence against humid paleoclimate. The original composition of Archean evaporites (Fig. 9) has been addressed by crystallographic work on interfacial angles of pseudomorphs in the 3.0 Ga Farrel Quartzite (Sugitani et al., 
2003), as well as in the 3.2 Ga Moodies Group (Nabhan et al., 2016), the $3.4 \mathrm{Ga}$ Kromberg Formation (Lowe and Worrell, 1999), the 3.4 Ga Strelley Pool Formation (Lowe, 1983; Allwood et al., 2007), the 3.5 Ga Apex Chert (Pinti et al., 2009) and the 3.5 Ga Dresser Formation (Lambert et al., 1978; Buick and Dunlop, 1990; Runnegar et al., $2001)$ to suggest that they were barite $\left(\mathrm{BaSO}_{4}\right)$, selenite-gypsum $\left(\mathrm{CaSO}_{4} \cdot 2 \mathrm{H}_{2} \mathrm{O}\right)$, and nahcolite $\left(\mathrm{NaHCO}_{3}\right)$. Evidence that sand crystals and nodules in the Farrel Quartzite were barite comes from glide twinning, and 63-64 wt \% $\mathrm{BaO}$ in relict cores of some pseudomorphs (Sugitani et al., 2003). Evidence against the former presence of gypsum in the Farrel Quartzite includes the lack of observed selenite fishtail twinning, and absence of pseudomorphs of equant-orthorhombic anhydrite $\left(\mathrm{CaSO}_{4}\right)$, which forms readily from elongate-monoclinic gypsum during shallow burial (Klimchouk, 1996). Equant cubes and rhombs in the Farrel Quartzite are iron-stained, and presumed to have been pyrite and siderite, respectively (Sugitani et al., 2003).

Archean silicified barite and nahcolite crystals have been attributed to hydrothermal vein crystallization (Runnegar et al., 2001; Pinti et al., 2009), or to precipitation from saline water (Lambert et al., 1978; Buick and Dunlop, 1990; Lowe, 1983; Lowe and Worrell, 1999; Sugitani et al., 2003; Allwood et al., 2006; Shen et al., 2009). These alternatives may be reasonable for other cases, but are not favored for the Farrel Quartzite because its crystal pseudomorphs have common inclusions (Fig. 8C-E), zones of dissolution (Fig. 8D-E), and dusty rims (Fig. 8C), resembling other Archean pedogenic evaporates (Nabhan et al., 2016). Dissolution planes, birdseye textures, enterolithic folds and nodules are additional field evidence of alternating desiccation and wetting (Sugitani et al., 2003). Nahcolite and barite are widespread as crystals, 
spherulites and nodules in sodic soils (Kohut and Durdas, 1993; Shahid and Jenkins, 1994; Howari et al., 2002; Jennings and Driese, 2014) and playa lake crusts (Hay, 1968; Renaut and Tiercelin, 1994). Nahcolite also forms from the weathering of natrocarbonatite lavas (Zaitsev and Keller, 2006), but the flat REE patterns of Farrel Quartzite rules out carbonatite tuffs (Sugahara et al., 2010; Retallack and Kirby, 2007). In playa lakes of semi-arid regions, nahcolite is precipitated within sediment below the surface (Hay, 1968; Eugster, 1969; Smith, 1979), but large crystal fans and lawns comparable with the Kari paleosol have only been reported for pre-Quaternary evaporites (Bradley, 1973; Surdam and Stanley, 1979; Larsen 2008; Garcia-Veigas et al., 2013). In modern soils, nahcolite and barite crystals and spherulites are generally microscopic (Kohut and Durdas, 1993; Shahid and Jenkins, 1994; Howari et al., 2002), but some soils have barite nodules up to $3.8 \mathrm{~cm}$ in diameter (Jennings and Driese, 2014; Jennings et al., 2015), like those of paleosols (Retallack and Kirby, 2007; Jennings et al., 2015).

Nahcolite has been reported in playa lakes and soils receiving 200-500 mm mean annual precipitation (Kohut and Durdas, 1993; Shahid and Jenkins, 1994; Howari et al., 2002), but its presence is more strongly controlled by the partial pressure of carbon dioxide than by paleoclimate (Eugster, 1966; Jagniecki et al., 2015). Pedogenic barite, on the other hand, is best known from humid forested soils with 1000-1200 mm mean annual precipitation, and may be controlled by microbially induced precipitation, or by redox changes at the water table, rather than by paleoclimate (Retallack and Kirby, 2007; Jennings et al., 2014). The growth of barite is favored by acid sulfate weathering at low $\mathrm{pH}(<3)$, but that of gypsum at higher $\mathrm{pH}$ (4-9: Carson et al., 1982). There is as yet no clear relationship between the depth of barite or nahcolite growth, and mean annual 
precipitation as there is for gypsum (Retallack and Huang, 2010). Thus it is puzzling that crystals of both nahcolite and barite are confined to a specific horizon (By) within the paleosols, and morphologically comparable with gypsic horizons in paleosols of Earth (Retallack and Huang, 2010) and Mars (Retallack, 2014). The growth of salts may have been suppressed in thin $(5-10 \mathrm{~cm})$ uppermost horizons of Archean and Martian paleosols by surficial moisture and carbonic acid from biological productivity, as in desert soils of Earth (Retallack, 2009).

\subsection{Atmospheric $\mathrm{CO}_{2}$}

High levels of carbon dioxide are critical for the precipitation and maintenance of nahcolite (Eugster, 1966). It is a rare mineral in surficial environments today because current atmospheric levels of only $408 \mathrm{ppm} \mathrm{CO}_{2}$ make it prone to recrystallization to trona $\left(\mathrm{Na}_{3}\left(\mathrm{CO}_{3}\right)\left(\mathrm{HCO}_{3}\right) \cdot 2 \mathrm{H}_{2} \mathrm{O}\right)$ or natron $\left(\mathrm{Na}_{2} \mathrm{CO}_{3} \bullet 10 \mathrm{H}_{2} \mathrm{O}\right)$. As for other greenhouse crises (Lowenstein and Demicco, 2006), nahcolite crystal pseudomorphs in the Kari paleosol may be evidence of at least $945 \mathrm{ppm} \mathrm{CO}_{2}$ in the atmosphere at temperatures of 10-11 ${ }^{\circ} \mathrm{C}$ (Jagniecki et al., 2015).

Much higher Archean $\mathrm{CO}_{2}$ levels (100-1000 times present atmospheric level or 30,000 to $300,000 \mathrm{ppm}$ ) have been inferred by Lowe and Tice (2004) from nahcolite formation in South Africa at assumed Archean temperatures of $70^{\circ} \mathrm{C}$, but such high temperatures are unlikely given more recent oxygen and hydrogen isotopic studies (Hren et al., 2009), preservation of quartz (Sleep and Hessler 2006), and application of paleosol paleothermometers used here (Óskarsson et al., 2012). A minimum level of 2500 ppm $\mathrm{CO}_{2}$ has been inferred from 3.2 Ga ferrous-carbonate weathering rinds (Hessler et al., 
2004), but such fluvial pebbles may have been isolated from the atmosphere by groundwater. Estimates of about 3,000 $\mathrm{pm} \mathrm{CO}_{2}$ comes from iron mineral stability in banded iron formations (Lowe and Tice, 2004; Ohmoto et al., 2004), which also reflect aquatic rather than atmospheric levels. A maximum level of $36,000 \mathrm{ppm} \mathrm{CO}_{2}$ has been inferred from paleosols ranging in age from 2.75-2.2 Ga because of a presumed lack of siderite in paleosols (Rye et al., 1995). This estimate suffers from choice of metamorphic rather than pedogenic mineral thermodynamic data (Sheldon, 2006), and there are rhombic pseudomorphs in Farrel Quartzite that may have been siderite (Sugitani et al., 2003). An estimate of 1,500 to $9,000 \mathrm{ppm}$ atmospheric $\mathrm{CO}_{2}$ at $3.0 \mathrm{Ga}$ comes from chemical weathering of the Jericho Dam paleosol of South Africa (Grandstaff et al., 1986). This much $\mathrm{CO}_{2}$ would result in acid rain (pH 4.0-4.5 according to Ohmoto et al., 2004), and soil-microbial $\mathrm{CO}_{2}$ and $\mathrm{H}_{2} \mathrm{SO}_{4}$ could drop soil water $\mathrm{pH}$ to 3 , and thus favor the abundant barite precipitation observed (Carson et al., 1982).

Even the most extreme of these estimates is short of the amount needed for a greenhouse capable of maintaining temperate Archean paleotemperatures given the faint young sun, and other greenhouse gases are required, including water vapor, ammonia, sulfur oxides, and methane (Ohmoto et al., 2004; Rosing et al., 2010; Kasting and Kirschvink, 2012). Much methane would have come from methanogenesis inferred from isotopic values of small spheroids (House et al., 2013) in Farrel Quartzite paleosols and allowed by low (160 ppm) $\mathrm{H}_{2}$ values likely for the Archean (Kasting and Kirschvink, 2012). An atmosphere with three times the current mass of $\mathrm{N}_{2}$ and a $\mathrm{H}_{2}$ mixing ratio of 0.1, would also have created an adequate greenhouse (Wordsworth and Pierrehumbert, 2013), but $\mathrm{N}_{2}$ in the atmosphere was limited to 1.1 to 0.5 bars, judging from nitrogen and 
argon isotopic ratios in fluid inclusions of the $3.5 \mathrm{Ga}$ Dresser Formation of Western Australia (Marty et al., 2013). Atmospheric pressure is constrained to no more than twice the modern value by $2.7 \mathrm{Ga}$ raindrop imprints (Som et al., 2012) and no more than half the modern value by $2.7 \mathrm{Ga}$ vesicle sizes in lava flows (Som et al., 2016). The volcanogenic greenhouse gas $\mathrm{SO}_{2}$ proposed on theoretical grounds for early Mars (Halevy et al., 2007) and early Earth (Claire et al., 2014) is compatible with the abundance of sulfate in paleosols of the Farrel Quartzite.

\subsection{Atmospheric $\mathrm{O}_{2}$}

Very low levels of atmospheric oxygen are evident from paleosols of the Farrel Quartzite because of their high ferrous to ferric iron ratios, comparable with swamp soils today exhausted of oxygen by microbial respiration (Retallack, 2001). However, the Farrel Quartzite paleosols were not waterlogged, but exposed to air as indicated by dissolution planes, birdseye textures, enterolithic folds and nodules of evaporitic mineral pseudomorphs (Sugitani et al., 2003). No highly oxidized minerals such as hematite or goethite were observed in fresh samples of the Farrel Quartzite paleosols.

A reasonable estimate of 0.002 to $0.1 \%$ atmospheric $\mathrm{O}_{2}$ for $3.0 \mathrm{Ga}$ is derived from chemical weathering of the Jericho Dam paleosol of South Africa and associated uraniferous conglomerates (Grandstaff et al., 1986). The Jericho Dam paleosol has been considered altered by hydrothermal fluids or by burial gleization of organic acids after formation in an oxidizing atmosphere (Ohmoto, 1996) of at least $0.3 \% \mathrm{O}_{2}$. However, there is no clear hydrothermal enrichment of heavy rare earth elements in the Jericho Dam profile (Kimberly and Grandstaff, 1986). Furthermore, burial gleization in paleosols 
of Triassic forest ecosystems (which were much more productive than envisaged for the Archean) extends to a depth of only $30 \mathrm{~cm}$ (Retallack, 1997), an order of magnitude less than the $3.3 \mathrm{~m}$ required to explain the deep spike in ferrous iron within the Jerico Dam paleosol (Grandstaff et al., 1986; Kimberly \& Grandstaff, 1986). These objections do not apply to the Nsuze paleosols of South Africa, geologically younger at $2.9 \mathrm{Ga}$, and with a lack of oxidative $\mathrm{Cr}$ and $\mathrm{U}$ recycling suggestive of 0.006 to $0.001 \% \mathrm{O}_{2}$ in the atmosphere (Crowe et al., 2013). Comparable estimates of 0.002 to $0.02 \% \mathrm{O}_{2}$ come from cerium anomalies, despite potash metasomatism and hydrothermal heavy rare earth enrichment of the 3.0-3.3 Ga Keonjhar paleosol deep weathering remnant of India (Mukhopadhyay et al., 2014). Redox-sensitive minerals including pyrite $(\mathrm{FeS})$, uraninite $\left(\mathrm{UO}_{2}\right)$, siderite $\left(\mathrm{FeCO}_{3}\right)$ and gersdorfffite (NiAsS) are common (57-85\%) in heavy mineral separations from fluvial siliciclastic sediments some 3.2-2.7 Ga in age in the Pilbara region (Rasmussen and Buick, 1999). This result has been challenged for pyrite in Pilbara sediments (Kojima et al., 1998), but the rounded nature of both authigenic framboids and detrital pyrite makes such distinctions difficult (Fig. 5F-H). Such grains could survive atmospheric oxidation by rapid burial in tectonically active regions (Ohmoto et al, 1999), but rapid burial was not the case considering the durations of soil formation in the Farrel Quartzite estimated in section 9.3. Low $\mathrm{O}_{2}$ and consequent lack of an ozone layer in the stratosphere is also indicated by mass-independent fractionation of sulfur isotopes in Archean pyrites and barites of the Pilbara region (Ueno et al., 2008; Shen et al., 2009) and Barberton Mountain Land of southern Africa (Roerdink et al., 2012).

\subsection{Microbiota.}


Microfossils in paleosols of the Farrel Quartzite have been studied by numerous methods but not taxonomically (Sugitani et al., 2007; Grey and Sugitani, 2009; Oehler et al., 2010; House et al., 2013). This account evaluates the five recognized morphotypes recognized by Sugitani et al. (2011), both from the perspectives of paleobotanical form taxonomy and of biological affinities (Table 3). This is not the full taxonomic study these microfossils deserve, but a provisional study using only comparable fossil taxa already described.

The Farrel Quartzite microbiota has some similarities with microfossils described from a locality $4 \mathrm{~km}$ west of old Panorama Homestead in the East Pilbara region (Awramik et al., 1983), which includes Archaeosphaeroides pilbarensis, resembling the Farrel Quartzite diffuse-wall spheroids, and Archaeotrichon contortum, resembling Farrel Quartzite filaments. The Panorama Homestead locality is currently mapped within the 3.5 Ga Mt Ada Basalt (Van Kranendonk, 2006; Hickman, 2013), but the exact location and geological setting of these microfossils are uncertain (Awramik et al., 1983). Some specimens of Archaeosphaeroides pilbarensis have walls comparable with the foldedwall spheroids of Sugitani et al. (2011), and their other two morphotypes with simple walls and thick walls fit within the same generic, if not specific, concept. The small spheroids in the Farrel Quartzite are comparable with the form species Archaeosphaeroides barbertonensis known from the Fig Tree Group near Barberton, South Africa (Schopf and Barghoorn, 1967), and assigned to the 3.2 Ga Haki Ironstone Member of the Sheba Formation (Lowe and Byerly, 1999).

Spindle-shaped microfossils in the Farrel Quartzite are distinctive, with a bulging cavity containing small internal bodies and a lateral rib that extends to a point at either 
end (Sugitani et al., 2007, 2009). Comparable spindle-shaped microfossils also have been reported from the 3.4 Ga Strelley Pool Formation of Western Australia (Sugitani et al., 2013), the 3.4 Ga Kromberg Formation of South Africa (Walsh, 2010), the 3.2 Ga Clutha Formation of South Africa (Javaux et al., 2010), and the 1.3 Ga Kendall River Formation of Arctic Canada (Horodyski and Donaldson, 1980; Kah et al., 2006). These spindles deserve their own new form-generic name based on the best studied material of Sugitani et al. (2011), but have been compared with the acritarch genera Pterospermopsis, Pterospermella, and Pterospermopsimorpha by Sugitani et al. (2009). All three acritarch taxa are double-walled, near spherical with narrow flanges, and have either no projections (Timofeev, 1966), or more than two blunt-ending projections (Eisenack, 1972; Yankauskas, 1980; Samuelsson et al., 1999), unlike the acutely tipped, simple-walled spindles of the Farrel Quartzite. The Farrel Quartzite spindle-shaped microfossils are commonly clustered with their ends continuous with filaments that appear to join them together, and, in addition, have small internal bodies (Sugitani et al., 2007, 2009). The form genus Primoflagella of the Ediacaran Kotlin Formation of Russia shares these characters, but has only one end tapering to filaments while the other end is blunt (Gnilovskaya, 1983). The Farrel Quartzite spindles are generally similar to Eupoikilofusa cloudii from the Cambrian Gouhou and Xiamaling Formations of China (Xing, 1987; Yin, 1987), and to Eupoikilofusa sp. from the 1.2 Ga Society Cliffs Formation of Baffin Island (Hofmann and Jackson, 1991). Canadian Arctic permineralizations show a similar curvature as the Farrel Quartzite spindles and some have filaments attached at one end. Eopoikilofusa is the most similar valid form genus to the Farrel Quartzite microfossil spindles. 
The Farrel Quartzite also contains numerous perfectly spherical opaque grains of pyrite, which are not microfossils, but likely framboids, and may represent results of microbial sulfur reduction (Sawlowicz, 1993). Archean biological sulfate reduction and atmospheric sources of sulfur come from fractionations of sulfur isotopes in pyrite associated with barite of the 3.5 Ga Dresser Formation of Western Australia (Ueno et al., 2008; Shen et al., 2009). Like microfossils, framboids were found in both matrix and clasts, but in some cases the framboids are so regularly arranged just inside the grain edge (Fig. 5F-G) that they may mark cavities occupied by endolithic organisms (McLoughlin et al., 2009).

There also are rare sinuously deformed fragments of microbial mats up to $1 \mathrm{~mm}$ long in the Farrel Quartzite (Sugitani et al., 2007, fig. 10; Sugitani et al., 2010, fig. 7AC). For these fragments, the ichnogenus Eoclathrus is suitable, although that genus is based on dimpled impressions rather than permineralizations, and has been regarded as problematic (Häntzschel, 1975). These mat fragments have fine lamination characteristic of aquatic microbial mats (Retallack, 2012), which contrasts with the massive to brecciated matrix of most of the microfossils in paleosols (Fig. 9A-B). Similar mat fragments have been described from intertidal facies of the 3.2 Ga Moodies Group of South Africa (Heubeck, 2009; Homann et al., 2015), and the Farrel Quartzite microbial mat fragments may have been derived from tidal flats nearby. The detachment of fragments of laminated aquatic microbial mats is a key feature distinguishing them from microbial earths, in which microbes are mixed with unlaminated grains (Retallack, 2012), as envisaged for paleosols of the Farrel Quartzite. 
Biological affinities of the Farrel Quartzite microfossils are inferred partly from their morphology and partly from their carbon isotopic composition (Table 3; House et al., 2013). Unusually light carbon isotopic composition (-33.8 to $-44.2 \delta^{13} \mathrm{Corg}$ ) of small spheroids comparable with Archaeosphaeroides barbertonensis are comparable with methanotrophic Proteobacteria and methanogenic Archaea (Schidlowski, 2001). Archaeospheroides barbertonenis is larger than most methanotrophs, although Archaea such as Methanosarcina barkeri have cells $4 \mu \mathrm{m}$ diameter and spherical walled colonies $10 \mu \mathrm{m}$ in diameter (Sowers et al., 1993). Methanogenesis is also evident from isotopic composition of methane in fluid inclusions from the $3.5 \mathrm{Ga}$ Dresser Formation of Western Australia (Ueno et al., 2006).

The large spheroids comparable with Archaeosphaeroides pilbarensis also have a distinctive carbon isotope composition (-34.3 to $\left.-38.4 \delta^{13} \mathrm{Corg}\right)$ comparable with that of purple sulfur bacteria (Chromatiaceae), which is unlike that of other bacteria including Cyanobacteria, Chloroflexi or Chlorobiaceae (Schidlowski, 2001). Purple sulfur bacteria have an array of morphologies and characteristic arrays (Fjerdingstad, 1979), but modern forms comparable with the Farrel simple wall spheroids are Chromatium obovatum (Fjerdingstad, 1979), while diffuse wall spheroids superficially resemble Thiophaeococcus mangrovi (Kumar et al., 2009), thick-walled spheroids like Rhodothece nuda (Fjerdingstad, 1979) and folded-wall spheroids like Chromatium densegranulatum (Fjerdingstad, 1979).

Eupoikilofusa microfossil spindles have been regarded as marine plankton because of their wide geographic distribution, "flanged lenticular shape, occasional internal vacuole-like structures, and the possible association with small non-clustered 
spheroids" (House et al., 2013). A. planktonic life style, however, is unlikely considering two non-hydrodynamic features: their connection by filaments into bunches, and their asymmetric curve and lateral ridge like a calzone (Fig. 5C-E). Internal hollows and associated spheroids are more likely spores or other propagules, than internal or remnant vacuoles. Farrel Quartzite filaments have a narrow range of isotopic composition because only three were analyzed (-34.4 to $\left.-36.3 \delta^{13} \mathrm{Corg}\right)$, but eight spindles from this and other Pilbara Archean cherts (House et al., 2013; Lepot et al., 2013) had a wide spread of values (-35.6 to $\left.-40.5 \delta^{13} \mathrm{Corg}\right)$, straddling values of both purple sulfur bacteria and methanogens as would be expected of heterotrophic bacteria (Schidlowski, 2001). Attachment of spindles of cf. Eupoikilofusa to Archaeotrichon threads (Sugitani et al., 2007) is comparable with Primoflagella (Gnilovskaya, 1983), and as in that case, can be interpreted as sporangia of actinobacteria. Comparable smooth sporangia with apical spines and attached to the ends of hyphae are found in living Streptosporangium roseum (Nolan et al., 2010). If cf. Eupoikilofusa from the Farrel Quartzite were actinobacteria, then they are much older than the hitherto earliest known actinobacteria of the $2.2 \mathrm{Ga}$ Gowganda Formation of Canada (Jackson, 1967). Nevertheless, actinobacteria on land would explain the organic-lean nature of paleosols, including the 3.0 Ga Jericho Dam paleosol of South Africa (Grandstaff et al., 1986), and a $2.7 \pm 0.3$ Ga molecular divergence of Actinobacteria (Battistuzzi and Hedges, 2009).

Sulfur bacteria (Chromatiaceae and Chlorobiaceae; Youssef et al., 2010) play a major role in precipitation of barite in modern cold sulfur springs within $12 \mathrm{~m}$ of the source, as demonstrated by diel fluctuations in aqueous sulfate and incubations, and stable isotopic comparisons from source to sink at Zodletone Spring, Oklahoma (Senko et 
al., 2004). Soil around Zodletone Spring is black in contact with the water, but gray with alunogen $\left(\mathrm{Al}_{2}\left(\mathrm{SO}_{4}\right)_{3} \bullet 17 \mathrm{H}_{2} \mathrm{O}\right)$ and white with gypsum $\left(\mathrm{CaSO}_{4} \cdot 2 \mathrm{H}_{2} \mathrm{O}\right)$ above the water (Donovan et al., 1988). Zodletone barite tufa shows a mix of groundwater features, such as cavity filling pendant and erect fans, and soil features, such as such as 6-mm-diameter barite roses with growth chevrons, suggestive of fluctuating water levels. Less similar to Archean paleosol barite is the barite tufa of Flyebye Springs in the Canadian Northwest Territories (Bonny and Jones, 2008a) and of Jasper Cold Sulphur Springs Alberta (Bonny and Jones, 2008b). Both Canadian springs are more heavily vegetated than Zodletone Spring and their barite tufas are distinctly laminated or stromatolitic with submillimetric barite as isopachous coatings and replacements of microbes, along with small crystals and spherulites. Crystals and nodules are also typical of barite in modern soils (Kohut and Durdas, 1993; Shahid and Jenkins, 1994; Howari et al., 2002; Jennings and Driese, 2014), in which both sulfur-oxidizing and sulfur-reducing bacteria are limited in distribution by atmospheric oxygen. Methanogens and methanotrophs also are largely limited to oxygen-poor aquatic environments, such as the guts of ruminants, swamp soils and rice paddy (Conrad, 2007). In the anoxic atmosphere of the Archean, however, aquatic methanotrophs and sulfur bacteria would not have been excluded from the intermittently wet pores of soils that were mostly well drained.

Distinctive microfossil morphology associated with sulfate pseudomorphs in the Farrel Quartzite may be evidence of differences between microbiota of land and sea during the Archean. Archean marine assemblages are characterized by common septate filaments (Primaevifilum; Awramik et al., 1983; Schopf et al., 2007), although some of these may be carbon-displacing vermicular phyllosilicate (Brasier et al., 2015; Wacey et 
al., 2016). In contrast, likely non-marine assemblages described here are characterized by microfossil spindles (cf. Eopoikilofusa: Fig. 5C-E), interpreted as actinobacteria. The many spheroids of Archaeosphaeroides in the Farrel Quartzite paleosols (Fig. 5A-B) are interpreted here as photosynthetic sulfur bacteria responsible for the accumulation of barite in the profiles and fueling the activity of sulfate-reducing bacteria represented by framboids (Fig. 5F-H). This confirms geochemical modelling that envisages evolution of the sulfur cycle on land before it extended to the sea (Stüeken et al., 2012). Archean sulfur isotopic evidence has been used to infer $<2.5 \mu \mathrm{M}$ marine sulfate, which is $<0.01$ $\%$ of modern marine sulfate (Crowe et al., 2014; Zelezhinskaia et al., 2014), but microbial sulfate reduction is evident from shallow-marine to lagoonal Archean carbonates (Paris et al., 2014). Sulfate may have been limited to only the shallowest parts of the Archean ocean, but the paleosols described here and by Nabhan et al. (2016) are evidence of widespread Archean sulfate on land.

\section{Conclusions}

Paleosols of the Farrel Quartzite provide a first quantitative appraisal of Archean microbial earth communities (Retallack, 2012). Morphology and isotopic composition allow educated guesses on the nature of the various microfossil morphotypes. The distinctive microfossil spindles (Fig. 5C-E), provisionally referred to cf. Eupoikilofusa (Hofmann and Jackson, 1991), are attached to and closely associated with fine filaments comparable with the hyphalike microfossil genus Archaeotrichon (Awramik et al., 1983). The spindles are hollow structures which have internal bodies (Sugitani et al., 2007), like spores of actinobacterial sporangia (Battistuzi and Hedges, 2009; Nolan et al., 2010). 
Both cf. Eupoikilofusa and Archaeotrichon have a wide range of isotopic composition (House et al., 2013), perhaps reflecting a varied diet. Archean paleosols of Mt Grant also include a variety of spherical cells generally similar to the microfossil genus Archaeosphaeroides (Awramik et al., 1983). Small (5-15 $\mu \mathrm{m}$ diameter) spheroids in clusters (Fig. 2A-B), have a distinctive light isotopic composition (-33.8 to $\left.-44.2 \delta^{13} \mathrm{Corg}\right)$ of methanogens (Schidlowski., 2001; House et al., 2013). Methanogenic bacteria and archaea are mostly smaller than the fossils, but Archaea such as Methanosarcina barkeri have coccoids up to $4 \mu \mathrm{m}$ in diameter and spherical walled colonies $10 \mu \mathrm{m}$ in diameter (Sowers et al., 1993). Large (10-60 $\mu \mathrm{m}$ diameter) spheroids with heavier isotopic composition (-34.3 to $\left.-38.4 \delta^{13} \mathrm{C}\right)$ than photosynthetic bacteria (Cyanobacteria), green sulfur bacteria (Chlorobiacaeae) or green non-sulfur bacteria (Chloroflexiacae), are isotopically (Schidlowski, 2001) comparable with purple sulfur bacteria (Chromatiaceae).

Such biological affinities support other indications of anaerobic soil forming conditions. High ferrous/ferric molecular weathering ratios (Fig. 6) and iron depletion (Fig.11) from the paleosols is comparable with that of swamp soils today (Retallack, 2001). These paleosols were not waterlogged because they are dominated by evaporite sand-crystal pseudomorphs including long pseudohexagonal columns interpreted as nahcolite $\left(\mathrm{NaHCO}_{3}\right)$ in the Kari pedotype, and short rhombs and nodularized rhombs interpreted as barite $\left(\mathrm{BaSO}_{4}\right)$ in the Jurl and Jurnpa pedotypes (Sugitani et al., 2003). Disturbed lamination (Fig. 9A-B) and hydrolytic weathering (Figs. 6,11) in the profiles also are indications of free drainage, as in comparable soil profiles of Chile (Amundson et al., 2012) and Antarctica (Campbell and Claridge, 1987), and 3.7 Ga paleosols of Mars (Retallack, 2014). These thin sulfate-rich (A-By) paleosols, together with comparable 3.2 
Ga profiles in South Africa (Nahban et al., 2016), at last reveal the appearance of Archean alluvial soils.

The abundance of oxidized minerals such as pedogenic barite in the paleosols is surprising for anaerobic and methanogenic soils, and may have been due to biological oxidation by purple sulfur bacteria, as in cold sulfur springs today (Senko et al., 2004). The abundance of sulfate in these paleosols is especially surprising compared with likely Archean ocean concentrations of $<2.5 \mu \mathrm{M}$, which is $<0.01 \%$ of modern marine sulfate (Crowe et al., 2014). Sulfur may have been a limiting nutrient in the ocean, but not on land where phosphorus was mobilized as a limiting nutrient (fig. 11). Production of sulfate by microbial chemolithotrophy (Senko et al., 2004), rather than atmospheric oxidation (Crowe et al., 2014), may have been mainly in terrestrial environments during the Archean. Despite lack of ozone and thus high ultraviolet radiation in a near-anaerobic atmosphere of 3.0 Ga (Ueno et al., 2008; Shen et al., 2009), paleosols of the Farrel Quartzite show impressive biodiversity, biological productivity, and degree of chemical weathering (Fig. 6). Archean intertidal stromatolites (Allwood et al. 2006. 2007) are also evidence against traditional arguments that land surfaces were sterilized by ultraviolet radiation (Schopf, 1999). Soils may have been better than water as a refuge from ultraviolet light, because metabolically useful light energy is reflected from mineral faces and harmful light shielded by opaque grains (Sagan and Pollack, 1974). Archean soils were far from sterile and played a role in phosphorus, sulfur, iron, and carbon cycling.

\section{Acknowledgments}


The CAMCOR high-resolution and nanofabrication facility is supported by the W.M.

Keck Foundation, M.J. Murdoch Charitable Trust, Oregon Nanoscience and

Microtechnologies Institute, Air Force Research Laboratory (FA8650-05-1-5041), US

National Science Foundation (0923577, 0421086), and University of Oregon. We are also grateful for discussions with Bruce Runnegar, Martin Van Kranendonk, Malcolm Walter, James Farquhar, and Roger Buick.

\section{References}

Allwood, A.C., Walter, M.R., Kamber, B.Z., Marshall, C.P., Burch, I.W. 2006. Stromatolite reefs from the Early Archaean era of Australia. Nature 441, 714-718.

Allwood, A.C., Walter, M.R., Burch, I.W., Kamber, B.S. 2007. 3.43 billion-year-old stromatolite reef from the Pilbara Craton of Western Australia: ecosystem-scale insights to early life on Earth. Precambrian Research 158, 198-227.

Amundson, R., Dietrich, W., Bellugi, D., Ewing, S., Nishishima, K., Chong, E.S., Owen, J., Finkel, R., Heimsath, A., Stewart, B., Caffee, M. 2012. Geomorphological evidence for the late Pliocene onset of hyperaridity in the Atacama Desert. Geological Society of America Bulletin 124, 1048-1070.

Archean Biosphere Drilling Project. 2014. Strelley Pool core \# 8 tray photos. http://www.psu.edu/spacegrant/ABDP/abdp8treyphotos.htm accessed August 24, 2014.

Ashley, G.M., Goman, M., Hover, V.C., Owen, R.B., Renaut, R.W., Muasya, A.M. 2002. Artesian blister wetlands, a perennial water resource in the semi-arid Rift Valley of East Africa. Wetlands 22, 686-695. 
Awramik, S.M., Buchheim, H.P. 2009. A giant, Late Archean lake system: The Meentheena Member (Tumbiana Formation; Fortescue Group), Western Australia. Precambrian Research 174, 215-240.

Awramik, S.M., Schopf, J.W., Walter, M.R. 1983. Filamentous fossil bacteria from the Archean of Western Australia. Precambrian Research 20, 357-374.

Battistuzzi, F.U., Hedges, S.B. 2009. A major clade of prokaryotes with ancient adaptations to life on land. Molecular Biology and Evolution 26, 335-343.

Birnbaum, S.J., Wireman, J.W. 1985. Sulfate-reducing bacteria and silica solubility: a possible mechanism for evaporite diagenesis and silica precipitation in banded iron formations. Canadian Journal of Earth Sciences 22, 1905-1909.

Birnbaum, S.J., Wireman, J.W., Borowski, R. 1989. Silica precipitation induced by the anaerobic sulfate reducing bacterium Desulfovibrio desulfuricans: effects upon cell morphology and implications for preservation. In: Origin, evolution, and modern aspects of biomineralization in plants and animals (Crick, R.E., Ed.). Springer, New York, pp. 507-516.

Bonny, S.M., Jones, B. 2008a. Experimental precipitation of barite $\left(\mathrm{BaSO}_{4}\right)$ among streamers of sulfur-oxidizing bacteria. Journal of Sedimentary Research 78, 357365.

Bonny, S.M., Jones, B. 2008b. Petrography and textural development of inorganic and biogenic lithotypes in a relict barite tufa deposit at Flybye Springs, NT, Canada. Sedimentology 55, 275-303.

Bradley, W.H. 1973. Oil shale formed in desertic environment: Green River Formation, Wyoming. Geological Society of America Bulletin 84, 1121-1124. 
Brasier, M.D., Antcliffe, J., Saunders, M., Wacey, D. 2015. Changing the picture of Earth's earliest fossils (3.5-1.9 Ga) with new approaches and new discoveries. U.S. National Academy of Sciences Proceedings 112, 4859-4864.

Brimhall, G.H., Chadwick, O.A., Lewis, C.J., Compston, W., Williams, I.S., Danti, K.J., Dietrich, W.E., Power, M.E., Hendricks, D., Bratt, J. 1992. Deformational mass transport and invasive processes in soil evolution. Science 255, 695-702.

Buick, R., Dunlop, J.S.R. 1990. Evaporitic sediments of early Archean age from the Warrawoona, North Pole, Western Australia. Sedimentology 37, 247-277.

Burgman, A. 2007. Nyamal dictionary, English-Nyamal finderlist and topical wordlist. Wangka Maya Aboriginal Language Centre, South Hedland, Western Australia, $29 \mathrm{p}$.

Campbell, I.B., Claridge, G.G.C. 1987. Antarctica - soils, weathering processes and climate. Elsevier, Amsterdam, 367 p.

Carson, C.D., Fanning, D.S., Dixon, J.B. 1982. Alfisols and Ultisols with acid sulfate weathering in Texas. In: Acid sulfate weathering (Kittrick, J.A., Fanning, D.S., Hossner, L.R., Eds.). Soil Science Society of America Special Publication 10, $127-146$.

Claire, M.W., Kasting, J.F., Domagal-Goldman, S.D., Stuëken, E., Buick, R., Meadows, V.S. 2014. Modeling the signature of sulfur mass-independent fractionation produced in the Archean atmosphere. Geochimica Cosmochimica Acta 141, 365380.

Conrad, R. 2007. Microbial ecology of methanogens and methanotrophs. Advances in Agronomy 96, 1-63. 
Crowe, S.A., Døssing, L.N., Beukes, N.J., Bau, M., Kruger, S.J., Frei, R., Canfield, D.E. 2013. Atmospheric oxygenation three billion years ago. Nature 501, 535-538.

Crowe, S.A., Paris, G., Katsev, S., Jones, C.-A., Kim, S.-T., Zerkle, A.L., Nomosatyro, S., Fowle, D.A., Adkins, J.F., Sessions, A.L., Farquhar, J., Canfield, D.E. 2014. Sulfate was a trace constituent of Archean seawater. Science 346, 735-739.

Dawes, P.R., Smithies, R.H., Centofanti, J., Podmore, D.C. 1995. Sunrise Hill unconformity: a newly discovered regional hiatus between Archean granites and greenstones in the northeastern Pilbara Craton. Australian Journal of Earth Sciences 42, 635-639.

De Kock, M.D., Evans, D.A.D., Beukes, N.J. 2009. Validating the existence of Vaalbara in the NeoArchean. Precambrian Research 174, 145-154.

Derenne, S., Robert, F., Skrzypczak-Bonduelle, A., Gourier, D., Binet, L., Rouzaud, J.-N. 2008. Molecular evidence for life in the 3.5 billion year old Warrawoona chert. Earth and Planetary Science Letters 272, 476-480.

Donovan, R.N., Younger, P., Ditzell, C. 1988. Some aspects of the geology of Zodletone Mountain, southwestern Oklahoma. In: Geological Society of America Centennial Field Guide Southeast Section (Hayward, O.T., Ed.). Geological Society of America, Boulder, pp. 99-102.

Eisenack, A. 1972. Kritische Bemerkung zur Gattung Pterospermopsis (Chlorophyta Prasinophyceae). Neues Jahrbuch für Geologie und Paläontologie Monatshefte $10,596-601$. 
Eriksson, K.A. 1982. Geometry and internal characteristics of Archean submarine channel deposits, Pilbara Block, Western Australia. Journal of Sedimentary Petrology 52, 383-393.

Eriksson, K.A., Krapež, B., Fralick, P.W. 1994. Sedimentology of Archean greenstone belts: signatures of tectonic evolution. Earth Science Reviews 37, 1-88.

Eugster, H.P. 1966. Sodium bicarbonate minerals as indicators of $\mathrm{pCO}_{2}$. Journal of Geophysical Research 71, 3369-3377.

Eugster, H.P. 1969. Inorganic bedded cherts from the Magadi area, Kenya. Contributions to Mineralogy and Petrology 22, 1-31.

Fedo, C.M., Nesbitt, H.W., Young, G.M. 1995. Unraveling the effects of potsssium metasomatism in sedimentary rocks and paleosols, with implications for paleoweathering conditions and provenence. Geology 23, 921-924.

Fjerdingstad, E. 1979. Sulfur bacteria. ASTM Technical Publication 650, 121 p.

Flannery, D.T., Walter, M.R. 2012. Archean tufted microbial mats and the Great Oxidation Event: new insights into an ancient problem. Australian Journal of Earth Sciences 59, 1-11.

Food and Agriculture Organization. 1974. Soil map of the world. Volume I: Legend. U.N.E.S.C.O., Paris, 59 p.

Gallagher, T.M., Sheldon, N.D. 2013. A new paleothermometer for forest paleosols and its implications for Cenozoic climate. Geology 41, 647-651.

Garcia-Veigas, J., Gündoğan, J., Helvaci, C., Prats, E. 2013. A genetic model for Nacarbonate mineral precipitation in the Miocene Baypazari trona deposit, Ankara Province, Turkey. Sedimentary Geology 294, 310-327. 
Gnilovskaya, M.B. 1983. Vendotaenids. In: Upper Precambrian and Cambrian palaeontology of the East-European Platform (Urbanek, A. and Rozanov, A.Y., Eds.). Wydawnictwa, Warsaw, pp. 46-55.

Grandstaff, D.E., Edelman, M.J., Foster, R.W., Zbinden, E., Kimberley, M.M. 1986. Chemistry and mineralogy of Precambrian paleosols at the base of the Dominion and Pongola Groups (Transvaal, South Africa). Precambrian Research 32, 97-131.

Grey, K., Sugitani, K. 2009. Palynology of Archean microfossils (c. 3.0 Ga) from the Mount Grant area, Pilbara Craton, Western Australia: Further evidence of biogenicity. Precambrian Research 173, 60-69.

Halevy, I., Zuber, M.T., Schrag, D.P. 2007. A sulfur dioxide climate feedback on early Mars. Science 318, 1903-1907.

Häntzschel, W. 1975. Treatise on paleontology. Part W. Miscellanea Supplement 1 Trace fossils and Problematica. University of Kansas and Geological Society of America, Lawrence and Boulder, 269 p.

Harvey, H.R., Tuttle, J.H., Bell, J.T. 1995. Kinetics of phytoplankton decay during simulated sedimentation: changes in biochemical composition and microbial activity under oxic and anoxic conditions. Geochim. Cosmochim. Acta, 59, 33673377.

Hay, R.L. 1968. Chert and its sodium-silicate precursors in sodium-carbonate lakes of East Africa. Contributions to Mineralogy and Petrology 17, 255-274.

Hessler, A.M., Lowe, D.R., Jones, R.L., Bird, D.K. 2004. A lower limit for atmospheric carbon dioxide levels 3.2 billion years ago. Nature 428, 736-738. 
Heubeck, C. 2009. An early ecosystem of Archean tidal microbial mats (Moodies Group, South Africa, ca. 3.2 Ga). Geology, 37, 931-934.Hickman, A.H. 2004. Two contrasting granite-greenstone terranes in the Pilbara Craton, Australia: evidence for vertical and horizontal tectonic regimes prior to 2900 Ma. Precambrian Research 131, 153-172.

Hickman, A.H. 2013. Geology of the North Shaw 1:100 000 Sheet. Western Australia Geological Survey 1:100 000 Geological Series.

Hofmann, H.J. 2004. Archean microfossils and abiomorphs. Astrobiology 4, 35-36.

Hofmann, H.J., Jackson, G.D. 1991. Shelf-facies microfossils from the Uluksan Group (Proterozoic Bylot Supergroup), Baffin Island, Canada. Journal of Paleontology $65,361-382$.

Homann, M., Heubeck, C., Airo, A., Tice, M.M. 2015. Morphological adaptations of 3.22 Ga-old tufted microbial mats to Archean coastal habitats (Moodies Group, Barberton Greenstone Belt, South Africa). Precambrian Research 266, 47-64

Horodyski, R.J., Donaldson, J.A. 1980. Microfossils from the Middle Proterozoic Dismal Lakes Group, Arctic Canada. Precambrian Research 11, 125-159.

House, C.H., Oehler, D.Z., Sugitani, K., Mimura, K. 2013. Carbon isotopic analyses of ca. 3.0 Ga microstructures imply planktonic autotrophs inhabited Earth's early oceans. Geology 41, 651-654.

Howari, F.M., Goodell, P.C., Miyamoto, S. 2002. Spectral properties of salt crusts formed on saline soils. Journal of Environmental Quality 31, 1453-1461.

Hren, M.T., Tice, M.M., Chamberlain, C.P. 2009. Oxygen and hydrogen isotope evidence for a temperate climate 3.42 billion years ago. Nature 462, 205-208. 
Isbell, R.F. 1996. The Australian soil classification. C.S.I.R.O., Collingwood, Victoria, $152 \mathrm{p}$

Jackson, T.A. 1967. Fossil actinomycetes in middle Precambrian glacial varves. Science $155,1003-1005$.

Jagniecki, E.A., Lowenstein, T.K., Jenkins, D.M., Demicco, R.V. 2015. Eocene atmospheric $\mathrm{CO}_{2}$ from the nahcolite proxy. Geology 43, 1075-1078.

Javaux, E.J., Marshall, C.P., Bekker, A. 2010. Organic-walled microfossils in 3.2-billionyear-old shallow-marine siliciclastic deposits. Nature 463, 934-938.

Jennings, D.S., Driese, S.G. 2014. Understanding barite and gypsum precipitation in upland acid-sulfate soils: an example from a Lufkin Series toposequence, southcentral Texas, U.S.A. Sedimentary Geology 299, 106-118.

Jennings, D.S., Driese, S.G., Dworkin, S.I. 2015. Comparison of modern and ancient barite-bearing acid-sulfate soils using micromorphology, geochemistry and field relationships. Sedimentology 62, 1078-1099.

Kah, L.C., Bartley, K.H., Frank, T.D., Lyons, T.W. 2006. Reconstructing sea-level change from the internal architecture of stromatolite reefs: an example from the Mesoproterozoic Sulky Formation, Dismal lakes Group, Arctic Canada. Canadian Journal of Earth Sciences 43, 653-669.

Kamenetsky, V.S., Davidson, P., Mernagh, T.P., Crawford, A.J., Gemmell, J.B., Portnyagin, M.V., Shinjo, R. 2002. Fluid bubbles in melt inclusions and pillowrim glasses: high-temperature precursors to hydrothermal fluids? Chemical Geology 183, 349-364. 
Kasting, J., Kirschvink, J. 2012. Evolution of a habitable planet. In: Frontiers of Astrobiology [Impey, C., Lunine, J., Funes, J., Eds.]. Cambridge Univ. Press, New York, pp. 115-131.

Kim, J., Dong, H., Seabaugh, J., Newell, S.W., Eberl, D.D. 2004. Role of microbes in the smectite-to-illite reaction. Science 303, 830-832.

Kimberly, M.M., Grandstaff, D.E. 1986. Profiles of elemental concentrations in Precambrian paleosols in basaltic and granitic parent materials. Precambrian Research 32, 133-154.

Kiyokawa, S., Taira, A., Byrne, T., Bowring, S., Sano, Y. 2002. Structural evolution of the middle Archean coastal Pilbara terrane, Western Australia. Tectonics 21, doi:10.1029/2001TC001296.

Klimchouk, A. 1996. The dissolution and conversion of gypsum and anhydrite. International Journal of Speleology 21, 25-36.

Knauth, L.P., Lowe, D.R. 2003. High Archean climatic temperature inferred from oxygen isotope geochemistry of cherts in the 3.5 Ga Swaziland Supergroup, South Africa. Geological Society of America Bulletin 115, 566-580.

Kohut, C.K., Durdas, M.J. 1993. Evaporite mineralogy and trace-element content of saltaffected soils in Alberta. Canadian Journal of Soil Science 73, 399-409.

Konhauser, K.O., Phoenix, V.R., Bottrell, S.H., Adams, D.G., Head, I.M. 2001. Microbial silica interactions in Icelandic hot spring sinter: possible analogues for some Precambrian siliceous stromatolites. Sedimentology 48, 415-433. 
Kojima, S., Hanamuro, T., Hayashi, K., Haruna, M., Ohmoto, M. 1998. Sulphide minerals in Early Archean chemical sedimentary rocks of the eastern Pilbara district. Mineralogy and Petrology 64, 219-235.

Krapež, B. 1984. Sedimentation in a small, fault-bounded basin - Lalla Rookh Sandstone, East Pilbara Block. In: Archean and Proterozoic basins of the Pilbara, Western Australia - evolution and mineralization potential [Muhling, J., Groves, D.I., Blake, T.S., Eds.]. University of Western Australia Geology Department University Extension Publication 9, 89-110.

Kumar, P.A., Srinivas, N.R., Sasikala, C., Ramana, C.V., Imhoff, J.F. 2008. Thiophaeococcus mangrovi gen. nov., sp. nov., a photosynthetic, marine gammaproteobacterium isolated from the Bhitarkanika mangrove forest of India. International Journal of Systematics Evolution and Microbiology 58, 2660-2664.

Kyle, J.E., Schroeder, P.A., Wiegel, J. 2007. Microbial silicification in sinters from two terrestrial hot springs in the Uzon Caldera, Kamchatka, Russia. Geomicrobiology Journal 24, 627-641.

Lambert, I.B., Donnelly, T.H., Dunlop, J.S.R., Groves, D.I. 1978. Stable isotopic compositions of early Archean sulfate deposits of probably evaporitic and volcanogenic origins. Nature 276, 808-811.

Larsen, D. 2008. Revisiting silicate authigenesis in the Pliocene-Pleistocene Lake Tecopa beds, southeastern California: depositional and hydrological controls. Geosphere, 4, 612-639.

Lepot, K., Williford, K.H., Ushikubo, T., Sugitani, K., Mimura, K., Spicuzza, M.J., Valley, J.W. 2013. Texture-specific isotopic compositions in 3.4 Gyr old organic 
matter support selective preservation in cell-like structures. Geochimica Cosmochimica Acta, 112, 66-86.

Lipski, P. 1994. Structural framework and depositional history of the Bedout and Rowley Sub-basins. In: The sedimentary basins of Western Australia [Purcell, P.G., Purcell, R.R.,Eds.]. Petroleum Exploration Society of Australia, Perth, pp.769777.

London, D. 2008. The barite roses of Oklahoma. Mineralogical Record 39, 277-292.

Lowe, D.R. 1983. Restricted shallow-water sedimentation of early Archean stromatolitic and evaporitic strata of the Strelley Pool Chert, Pilbara Block, Western Australia. Precambrian Research 19, 239- 283.

Lowe, D.R. 2007. A comment on "Weathering of quartz as an Archean climatic indicator" by N.H. Sleep and A.M. Hessler. Earth and Planetary Science Letters $253,530-533$

Lowe, D.R., Byerly, G.R. 1999. Stratigraphy of the west-central part of the Barberton Greenstone Belt, South Africa. In: Geologic evolution of the Barberton Greenstone Belt, South Africa [Lowe, D.R., Byerly,G.R., Eds]. Geological Society of America Special Publication 329, 1-36.

Lowe, D.R., Tice, M.M. 2004. Geologic evidence for Archean atmospheric and climatic evolution: fluctuating levels of $\mathrm{CO}_{2}, \mathrm{CH}_{4}$, and $\mathrm{O}_{2}$ with an overriding tectonic control. Geology 32, 493-496.

Lowe, D,R,, Worrell, G.F. 1999. Sedimentology, mineralogy, and implications of silicified evaporites in the Kromberg Formation, Barberton Greenstone Belt, South Africa. In Geologic evolution of the Barberton Greenstone Belt, South 
Africa [Lowe, D.R., Byerly, G.R., Eds.). Geological Society of America Special Publication 329, 167-188.

Lowenstein, T.K., Demicco, R.V. 2006. Elevated Eocene atmospheric $\mathrm{CO}_{2}$ and its subsequent decline. Science 313, 1928.

Maliva, R.G., Knoll, A.H., Simonson, B.M. 2005. Secular change in the Precambrian silica cycle: insights from chert petrology. Geological Society of America Bulletin 117, 835-845.

Marty, B., Zimmermann, L., Pujol, M., Burgess, R., Philippot, P. 2013. Nitrogen isotope composition and density of the Archean atmosphere. Science 342, 101-104.

Maynard, J.B. 1992. Chemistry of modern soils as a guide to Precambrian fossil soils. Journal of Geology 100, 279-289.

McCaffrey, A.R., King, R.W., Payne, S.J., Lancaster, M. 2013. Active tectonics of northwestern U.S. inferred from GPS-derived surface velocities. Journal of Geophysical Research Solid Earth 118, 709-723.

McLoughlin, N., Furnes, H., Banerjee, N.R., Muehlenbachs, K., Staudigel, H. 2009. Ichnotaxonomy of microbial trace fossils in volcanic glass. Geological Society of London Journal 166, 159-169.

Mukhopadhyay, J., Crowley, Q.G., Ghosh, S., Ghosh, G., Charkrabarti, K., Misra, B., Heron, K., Bose, S. 2014. Oxygenation of the Archean atmosphere: new paleosol constraints from eastern India. Geology 42, 923-926.

Nabhan, S., Luber, T., Scheffler, T., Heubeck, C. 2016. Climatic and geochemical implications of Archean pedogenic gypsum in the Moodies Group ( 3.2 Ga), Barberton Greenstone Belt, South Africa. Precambrian Res. 275, 119-134. 
Neaman, A., Chorover, J., Brantley, S.L. 2005. Element mobility patterns record organic ligands in soils on early Earth. Geology 33, 117-121.

Nelson, D.R. 1998. Compilation of SHRIMP U-Pb zircon geochronology data 1997. Western Australia Geological Survey Record 1998/2, 1-242.

Nesbitt, H.W., Young, G.M. 1989. Formation and diagenesis of weathering profiles. Journal of Geology 97, 129-147.

Nolan, M,, Sikorski, J., Jando, M., Lucas, S., Lapidus, A., Del Rio, T.G., Chen, F., Tice, H., Pitluck, S., Cheng, J.F., Chertkov, O., Sims, D., Meincke, L., Brettin, T., Han, C., Detter, J.C., Bruce, D., Goodwin, L., Land, M., Hauser, L., Chang, Y.-J., Jeffries, C.D., Ivanova, N., Mavromatis, K., Mikhailova, N., Chen, A., Palaniappan, K., Chain, P., Rohde, M., Göker, M., Bristow, J., Eisen, J.A., Markowitz, V., Hugenholtz, P., Kyrpides, N.C., Klenk, H.-P. 2010. Complete genome sequence of Streptosporangium roseum type strain (NI 9100T). Standards of Genome Science 2, 29-31.

Novoselov, A.A., de Souza Filho, C.R. 2015. Potassium metasomatism of Precambrian paleosols. Precambrian Research 262, 67-83.

Oehler, D.Z., Robert, F., Walter, M.R., Sugitani, K., Meibom, A., Mostefaou, S., Gibson, E.K. 2010. Diversity in the Archean biosphere: new insights from NanoSIMS. Astrobiology 10, 413-424.

Ohmoto, H. 1996. Evidence in pre-2.2 Ga paleosols for the early evolution of atmospheric oxygen and terrestrial biota. Geology 24, 1135-1138. 
Ohmoto, H., Rasmussen, B., Buick, R. 1999. Redox state of the Archean atmosphere: evidence from detrital heavy minerals in ca. 3250-2750 Ma sandstones from the Pilbara Craton, Australia: comment and reply. Geology 27, 1151-1152.

Ohmoto, H., Watanabe, Y., Kumazawa, K. 2004. Evidence from massive siderite beds for a $\mathrm{CO}_{2}$-rich atmosphere before $\sim 1.8$ billion years ago. Nature 429, 395-399.

Óskarsson, B.V., Riishuus, M.S., Arnalds, O. 2012. Climate-dependent chemical weathering of volcanic soils in Iceland. Geoderma 189-190, 635-651.

Owen, R.A., Owen, R.B., Renaut, R.W., Scott, J.J., Jones, B., Ashley, G.M. 2008. Mineralogy and origin of rhizoliths on the margins of saline, alkaline Lake Bogoria, Kenya Rift Valley. Sedimentary Geology 203, 143-163.

Paris, G., Adkins, J.F., Sessions, A.L., Webb, S.M., Fischer, W.W. 2014. NeoArchean carbonate-associated sulfate records positive $\Delta^{33} S$ anomalies. Science 346,739 741.

Pinti, D.L., Mineau, R., Clement, V. 2009. Hydrothermal alteration and microfossil artefacts of the 3,465-million-year-old Apex chert. Nature Geoscience 2, 640-643.

Rasmussen, B., Buick, R. 1999. Redox state of the Archean atmosphere: evidence from detrital heavy minerals in ca. 3250-2750 Ma sandstones from the Pilbara Craton, Australia. Geology 27, 115-118.

Renaut, R.W., Tiecerlin, J.-J. 1994. Lake Bogoria, Kenya Rift Valley - a sedimentological overview. In: Sedimentology and geochemistry of modern and ancient saline lakes [Renaut, R.W., Last, W.M., Eds.]. Society for Sedimentary Geology Special Publication 50, 101-124. 
Retallack, G.J. 1997. Paleosols in the upper Narrabeen Group of New South Wales as evidence of Early Triassic paleoenvironments without exact modern analogues. Geological Society of Australia Journal 44, 185-201.

Retallack, G.J. 2001. Soils of the past. Blackwell, Oxford, 346 p.

Retallack, G.J. 2005. Pedogenic carbonate proxies for amount and seasonality of precipitation in paleosols. Geology 33, 333-336.

Retallack, G.J. 2009. Refining a pedogenic $\mathrm{CO}_{2}$ paleobarometer for quantifying the middle Miocene greenhouse spike. Palaeogeography Palaeoclimatology Palaeoecology 281, 57-65.

Retallack, G.J. 2011. Exceptional fossil preservation during $\mathrm{CO}_{2}$ greenhouse crises? Palaeogeography Palaeoclimatology Palaeoecology 307, 59-74.

Retallack, G.J. 2012. Criteria for distinguishing microbial mats and earths. In Microbial mats in siliciclastic sediments [Noffke, N., Chafetz, H., Eds]. Society of Economic Paleontologists and Mineralogists Special Paper 101, 136-152.

Retallack, G.J. 2013. Ediacaran life on land. Nature 493, 89-92.

Retallack, G.J. 2014. Paleosols and paleoenvironments of early Mars. Geology 42, 755758.

Retallack, G.J., Huang, C.-M. 2010. Depth to gypsic horizon as a proxy for paleoprecipitation in paleosols of sedimentary environments. Geology 38, 403406.

Retallack, G.J., Kirby, M.X. 2007. Middle Miocene global change and paleogeography of Panama. Palaios 22, 667-679. 
Rice, C.M., Ashcroft, W.A., Batten, D.J., Boyce, A.J., Caulfield, J.B.D., Fallick, A.E., Hole, M.J., Jones, E., Pearson, M.J., Rogers, G., Saxton, J.M., Stuart, F.M., Trewin, N.H., Turner, G. 1995. A Devonian auriferous hot spring system, Rhynie, Scotland. Geological Society of London Journal 152, 229-252.

Roerdink, D.L., Mason, P.R., Farquhar, J., Reimer, T. 2012. Multiple sulfur isotopes in Paleoarchean barites identify an important role for microbial sulfate reduction in the early marine environment. Earth and Planetary Science Letters, 331, 177-186.

Rosing, M.T., Bird, D.K., Sleep, N.H., Bjerrum, C.J. 2010. No climate paradox under the faint early Sun. Nature 464, 744-747.

Runnegar, B., Dollase, W.A., Ketcham, R.A., Colbert, M., Carlson, W.D. 2001. Early Archean sulfates from Western Australia first formed as hydrothermal barites not gypsum evaporates. Annual Meeting Geological Society of America Abstracts 33(6), A404.

Rye, R.O. 2005. A review of the stable-isotope geochemistry of sulfate minerals in selected igneous environments and related hydrothermal systems. Chemical Geology 215, 5-36.

Rye, R., Holland, H.D. 1998. Paleosols and the evolution of atmospheric oxygen: a critical review. American Journal of Science 298, 621-672.

Rye, R., Holland, H.D. 2000. Life associated with a 2.76 Ga ephemeral pond?: Evidence from Mount Roe \#2 paleosol. Geology 28, 483-486.

Rye, R., Kuo, R.H., Holland, H.D. 1995. Atmospheric carbon dioxide before 2.2 billion years ago. Nature 378, 603-605. 
Sagan, C., Pollack, J.B. 1974. Differential transmission of sunlight on Mars: biological implications. Icarus, 21, 490-495.

Sakurai, R., Ito, M., Ueno, Y., Kitajima, K., Maruyama, S. 2005. Facies architecture and sequence-stratigraphic features of the Tumbiana Formation in the Pilbara Craton, northwestern Australia: Implications for depositional environments of oxygenic stromatolites during the Late Archean. Precambrian Research 138, 255-273.

Samson, I.M., Liu, W., Williams-Jones, A.E. 1995. The nature of orthomagmatic hydrothermal fluids in the Oka carbonatite, Quebec, Canada: Evidence from fluid inclusions. Geochimica et Cosmochimica Acta, 59, 1963-1977.

Samuelsson, J., Dawes, P.R., Vidal, G. 1999. Organic-walled microfossils from the Proterozoic Thule Supergroup, Northwest Greenland. Precambrian Research 96, $1-23$.

Sawlowicz, Z. 1993. Pyrite framboids and their development: a new conceptual mechanism. Geologische Rundschau 82, 148-156.

Schidlowski, M. 2001. Carbon isotopes as biogeochemical recorders of life over $3.8 \mathrm{Ga}$ of Earth history: evolution of a concept. Precambrian Research 106, 117-134.

Schopf, J.W. 1999. Cradle of life; the discovery of Earth's earliest fossils. Princeton Univ. Press, Princeton, 392 p.

Schopf, J.W., Barghoorn, E.S. 1967. Alga-like fossils from the Early Precambrian of South Africa. Science 156, 508-512.

Schopf, J.W., Kudryavtsev, A.B., Czaja, A.D., Tripathi, A.B. 2007. Evidence of Archean life: Stromatolites and microfossils. Precambrian Research 158, 141-155. 
Senko, J.M., Campbell, B.S., Henriksen, J.R., Elshahed, M.S., Dewers, T.A., Krumholz, L.R. 2004. Barite deposition resulting from phototrophic sulphide-oxidising bacterial activity. Geochimica Cosmochimica Acta 68, 773-780.

Sergeev, V.N., Sharma, M., Shukla, Y. 2012. Proterozoic fossil Cyanobacteria. Palaeobotanist 61, 189-358.

Shahid, S.A., Jenkins, D.A. 1994. Mineralogy and micromorphology of salt crusts in Punjab, Pakistan. In: Soil Micromorphology: Studies in management and genesis [Ringrose-Voase, A.J., Humphreys, G.S., Eds.]. Elsevier, Amsterdam, pp. 799810.

Sheldon, N.D. 2006. Precambrian paleosols and atmospheric $\mathrm{CO}_{2}$ levels. Precambrian Research 147, 148-155.

Sheldon, N.D., Retallack, G.J., Tanaka, S. 2002. Geochemical climofunctions from North American soils and application to paleosols across the Eocene-Oligocene boundary in Oregon. Journal of Geology 110, 687-696.

Shen, Y., Farquhar, J., Masterson, A., Kaufman, A.J., Buick, R. 2009. Evaluating the role of microbial sulfate reduction in the early Archean using quadruple isotope systematics. Earth and Planetary Science Letters 279, 383-391.

Shibuya, T., Kitajima, K., Komiya, T., Terabayashi, M., Maruyama, S. 2007. Middle Archean ocean ridge hydrothermal metamorphism and alteration recorded in the Cleaverville area, Pilbara Craton, Western Australia. Journal of Metamorphic Geology 25, 751-767.

Siever, R. 1962. Silica solubility, $0^{\circ}-200^{\circ}$ C., and the diagenesis of siliceous sediments. Journal of Geology 70, 127-150. 
Sleep, N.H., Hessler, A.M. 2006. Weathering of quartz as an Archean climatic indicator. Earth and Planetary Science Letters 241, 594-602.

Smith, G.I. 1979. Subsurface stratigraphy and geochemistry of late Quaternary evaporites, Searles Lake, California. U.S. Geological Survey Professional Paper 1043, 1-130.

Smithies, R.H., Van Kranendonk, M.J., Hickman, A.H. 2004. Geology of the De Grey 1:100,000 sheet 2757. Geological Survey of Western Australia Explanatory Notes, Perth.

Soil Survey Staff. 2014. Keys to soil taxonomy. Natural Resources Conservation Service, Washington, DC, 600 p.

Som, S.M., Catling, D.C., Harnmeijer, J.P., Polivka, P.M., Buick, R. 2012. Air density 2.7 billion years ago limited to less than twice modern levels by fossil raindrop imprints. Nature 484, 359-362.

Som, S.M., Buick, R., Hagadorn, J.W., Blake, T.S., Perreault, J.M., Harnmeijer, J.P., Catling, D.C. 2016. Earth's air pressure 2.7 billion years ago constrained to less than half of modern levels. Nature Geoscience 9, 448-452.Sowers, K.R., Boone, J.E., Gunsalus, R.P. 1993. Disaggregation of Methanosarcina spp. and growth as single cells at elevated osmolarity. Applied Environmental Microbiology 59, 2832-3839.

Stüeken, E., Catling, D.C., Buick, R. 2012. Contributions to late Archean sulfur cycling by life on land. Nature Geoscience 5, 722-725.

Sugahara, H., Sugitani, K., Mimura, K., Yamashita, F., Yamamoto, K. 2010. A systematic rare-earth elements and yttrium study of Archean cherts at the Mount 
Goldsworthy greenstone belt in the Pilbara Craton: Implications for the origin of microfossil-bearing black cherts. Precambrian Research 177, 73-87.

Sugitani, K., Mimura, K., Suzuki, K., Nagamine, K., Sugisaki, R. 2003. Stratigraphy and sedimentary petrology of an Archean volcanic/sedimentary succession at Mt. Goldsworthy in the Pilbara Block, Western Australia: implications of evaporite (nahcolite) and barite deposition. Precambrian Research 120, 55-79.

Sugitani, K., Yamashita, F., Nagaoka, T., Yamamoto, K., Minamie, M., Mimurad, K., Suzuki, K. 2006. Geochemistry and sedimentary petrology of Archean clastic sedimentary rocks at Mt. Goldsworthy, Pilbara Craton, Western Australia: Evidence for the early evolution of continental crust and hydrothermal alteration. Precambrian Research 147, 124-147.

Sugitani, K., Grey, K., Allwood, A., Nagaoka, T., Mimura, K., Minami, M., Marshall, C.P., van Kranendonk, M.J., Walter, M.R. 2007. Diverse microstructures from Archean cherts at the Mt Goldsworthy Greenstone belt in the Pilbara Craton: implications for the origin of microfossil-bearing black cherts. Precambrian Research 158, 228-262.

Sugitani, K., Grey, K., Nagaoka, T., Mimura, K. 2009. Three dimensional morphological and textural complexity of Archean putative microfossils from the northeastern Pilbara Craton: indications of biogenicity of large $(>15 \mu \mathrm{m})$ spheroids and spindle-like structures. Astrobiology 9, 603-615.

Sugitani, K., Mimura, K., Walter, M.R. 2011. Farrel Quartzite microfossils in the Goldsworthy Greenstone Belt, Pilbara Craton, Western Australia: additional evidence for a diverse and evolved biota on the Archean Earth. In Stromatolites: 
interaction of microbes with sediments [Tewari, V.C., Seckbach, J., Eds]. Springer, Berlin, pp. 117-132.

Sugitani, K., Mimura, K., Nagaoka, T., Lepot, K., Takeuchi, M. 2013. Microfossil assemblage from the 3400 Ma Strelley Pool Formation in the Pilbara Craton, Western Australia: results from a new locality. Precambrian Research 226, 59-74.

Surdam, R.C., Stanley, K.O. 1979. Lacustrine sedimentation during the culminating phase of Eocene Lake Gosiute, Wyoming (Green River Formation). Geological Society of America Bulletin 90, 93-110.

Thompson, A.B. 1992. Metamorphism and fluids. In: Understanding the Earth [Brown, C.C., Hawkesworth, C.G., Wilson, R.C.L., Eds.]. Cambridge University. Press, Cambridge, pp. 222-248.

Thorne, A.M., Trendall, A.F. 2001. Geology of the Fortescue Group, Pilbara Basin, Western Australia. Geological Survey of Western Australia Bulletin 144, 1-249.

Timofeev, B.V. 1966. Mikropaleofitologicheskoe issledovanie drevnikh svit (Micropaleophytological investigations of ancient formations). Nauka, Moscow, $147 \mathrm{p}$.

Ueno, Y., Yamada, K., Yoshida, N., Maruyama, S., Isozaki, Y. 2006. Evidence from fluid inclusions for microbial methanogenesis in the early Archean era. Nature 440, 516-519.

Ueno, Y., Ono, S., Rumble, D., Maruyama, S. 2008. Quadruple sulfur isotopic analysis of ca. 3.5 Ga Dresser Formation: new evidence for microbial sulfate reduction in the early Archean. Geochimica Cosmochimica Acta 72, 5675-5691. 
Van Kranendonk, M.J. 2000. Geology of the North Shaw 1:100 000 Sheet. Western Australia Geological Survey 1:100 000 Geological Series Explanatory Notes, 86 p.

Van Kranendonk, M.J. 2006. Volcanic degassing, hydrothermal circulation and the flourishing of early life on Earth: a review of the evidence from c. 3490-3240 Ma rocks of the Pilbara Supergroup, Pilbara Craton, Western Australia. Earth Science Reviews 74, 197-240.

Van Kranendonk, M.J. 2010. Geology of the 1:100,000 Coongan Sheet. Western Australia Geological Survey Explanatory Notes, 67 p.

Van Kranendonk, M.J., Pirajno, F. 2004. Geochemistry of metabasalts and hydrothermal alteration zones associated with c. 345 Ga chert and barite deposits: implications for the geological setting of the Warrawoona Group, Pilbara Craton, Australia. Geochemical Exploration and Environment Analysis 4, 253-278.

Van Kranendonk, M.J., Hickman, A.H., Smithies, R.H., Williams, I.R., Bagas, L., Farrell, T.R. 2006. Revised lithostratigraphy of Archean supracrustal and intrusive rocks in the northern Pilbara Craton, Western Australia. Western Australia Geological Survey Record 2006/15, 57 p.

Van Kranendonk, M.J., Smithies, R.H., Hickman, A.H., Champion, D.C. 2007. Review: secular tectonic evolution of Archean continental crust: interplay between horizontal and vertical processes in the formation of the Pilbara Craton, Australia. Terra Nova 19, 1-38. 
Van Kranendonk, M.J., Philippot, P., Lepot, K., Bodorkos, S., Pirajno, F. 2008. Geological setting of Earth's oldest fossils in the ca. 3.5 Ga Dresser Formation, Pilbara Craton,Western Australia. Precambrian Research 167, 93-124.

Van Kranendonk, M.J., Smithies, R.H., Hickman, A.H., Wingate, M.T.D., Bodorkos, S. 2010.)Evidence for MesoArchean ( 3.2 Ga) rifting of the Pilbara Craton: The missing link in an early Precambrian Wilson cycle. Precambrian Research 177, $145-161$.

Wacey, D., Saunders, M., Brasier, M., Kong, C. 2016. Solving the controversy of the Earth's oldest fossils using electron microscopy. Microscopy Today 24, 12-16.

Walsh, M. 2010. Microbial mats on the early Earth: the Archean fossil record. In Microbial mats: modern and ancient microorganisms in stratified systems [Seckbach, J., Oren, A., Eds.]. Springer, Berlin, pp. 41-51.

Warren, J.K. 2006. Evaporites; sediments, resources and hydrocarbons. Springer, Berlin, $1036 \mathrm{p}$.

Wignall, P.B., Newton, R. 1998. Pyrite framboid diameter as a measure of oxygen deficiency in ancient mudrocks. American Journal of Science 298, 537-552.

Wijbrans, J.R., McDougall, I. 1987. On the metamorphic history of an Archean granitoidgreenstone terrane, east Pilbara, Western Australia, using the ${ }^{40} \mathrm{Ar} /{ }^{39} \mathrm{Ar}$ age spectrum technique. Earth and Planetary Science Letters 84, 226-242.

Wordsworth, R., Pierrehumbert, R. 2013. Hydrogen-nitrogen greenhouse warming in Earth's early atmosphere. Science 339, 64-67. 
Xing, Y.-S. 1987. Precambrian micropaleontology in our country, its development and application [in Chinese]. Professional Papers in Stratigraphy and Paleontology 17, $8-28$.

Yankauskas, T.V. 1980. Shishenyakskaya mikrobiota verchnego rifeya Yuzhnogo Urala (Shishenya microbiota from the upper Riphean of the Urals). Doklady Akademia Nauk SSSR 251, 190-192.

Yin, L.-M. 1987. Microbiotas of latest Precambrian sequences in China (in Chinese). In Stratigraphy and palaeontology of systemic boundaries in China. PrecambrianCambrian boundary [Zhang, W.T., Ed.]. Academia Sinica, Nanjing, pp. 415-522. Youssef, N.H., Couger, M.B., Elshahed, M.S. 2010. Fine-scale bacterial beta diversity within a complex ecosystem (Zodletone Spring, OK, USA): the role of the rare biosphere. Plos One 5, e12414-1241.

Zaitsev, A.N., Keller, J. 2006. Mineralogical and chemical transformation of Oldoinyo Lengai natrocarbonatites, Tanzania. Lithos 91, 191-207.

Zhao, S.R., Tan, J., Wang, W.K. 1998. Morphology and growth mechanism of the chrysanthemum stone in South China. Journal of Mineralogy Petrology 18, 1-6.

Zhelezinskaia, I., Kaufman, A.J., Farquhar, J., Cliff, J. 2014. Large sulfur isotope fractionations associated with NeoArchean microbial sulfate reduction. Science $346,742-745$.

Ziegenbalg, S.B., Brunner, B., Rouchy, J.M., Birgel, D., Pierre, C., Böttcher, M.E., Caruso, A., Immenhauser, A., Peckmann, J. 2010. Formation of secondary carbonates and native sulfur in sulfate-rich Messinian strata, Sicily. Sedimentary Geology 227, 37-50. 
Fig. 1. Location of studied section of Archean paleosols in the Farrel Quartzite near Mt Grant, Western Australia. Simplified after DeGrey 1:100,000 sheet geology (Smithies et al., 2004) with updated stratigraphic nomenclature (Van Kranendonk et al., 2006).

Fig. 2. Field photographs of named Archean paleosols from Western Australia: (A), Overview of contact between Farrel Quartzite and site studied here (arrow) and by Sugitani et al. $(2003,2007,2011)$ immediately below the Cleaverville Formation on the ridge $1.2 \mathrm{~km}$ east of Mt Grant, east Pilbara County, Western Australia: (B), Jurnpa clay loam paleosol above fluvial sandstones: $(\mathbf{C})$, Jurl clay loam paleosol in floodplain deposits: (D), Kari silty clay loam paleosol in floodplain deposits. Aboriginal and texture names are particular kinds of paleosols (pedotypes). Symbols A, By and C are interpreted soil horizons. Red colors of soil and cracks do not extend into fresh rock. Hammer handle for scale is $25 \mathrm{~cm}$ long.

Fig. 3. Measured section of Archean paleosols in the Farrel Quartzite near Mt Grant, Western Australia. Paleosol development scale is based on salt abundance and size (Retallack \& Huang, 2010), calcareousness is based on degree of reaction with dilute $(10 \%) \mathrm{HCl}$. Colors are largely gray with both greenish and bluish chroma from gley Munsell sheets (see also Fig. 6). 
Fig. 4. Geochemical indications of limited illitization (A-B) and silicification (C-J) bias in geochemical composition of Archean paleosols from near Mt Grant. Two samples of black chert in the upper Jurnpa paleosol form outliers (C-F), but there is no silicification trend in the remaining specimens (G-J).

Fig. 5. Selected microfossils and framboids from Farrel Quartzite, Western Australia (for comprehensive illustration see Sugitani et al., 2007, 2009, 2011): (A) clusters of large thick wall spheroid (left: some deformed by crystal growth) and small spheroid (right) morphotypes; (B) cluster of small spheroid morphotype; (C) spindle morphotype; (D-E) isolated and clustered spindles, respectively; (F-G) sandstone with grains of fossiliferous chert (gray) and quartz (white), including marginal opaque framboids of possible endolithic microbes; $(\mathbf{H})$ deformed biotite grain with pyrite framboids concentrated along selected cleavage planes. Thin sections in the Condon Collection of the Museum of Natural and Cultural History of the University of Oregon are (A-D) F118310B=R4336 from A horizon of Jurnpa clay loam, (E) F118311F=R4346 from C horizon of Ngumpu silty clay loam, (F-G) F118310E=R4339 from By horizon of Jurnpa clay loam, and (H) R4340 from C horizon of Jurnpa clay loam.

Fig. 6. Microfossil distribution, petrography and chemical weathering ratios of Archean paleosols from Western Australia: (A) Sections measured in the field with tape and Munsell Soil Color Chart; (B) Microfossil morphotypes after Sugitani et al. (2011) tallied from 10 photomicrographs from each sampled level: (C) Grain size and mineral content 
from point counting petrographic thin sections: (D) Molecular weathering ratios based on whole rock XRF analyses (See Supplementary Data for tabulated data).

Fig. 7. Microfossil preservation in the type Jurnpa paleosol of the Farrel Quartzite, Western Australia: (A-B) backscatter scanning electron micrographs showing degraded organic spheroids larger than and little displaced by neomorphic quartz (small gray fields) and a large pyrite framboids (white in A) and crystals (white in B): (C) transmission electron micrograph of spindle microfossil (upper) showing ropy degradation of organic matter (above), compared with particulate organic matter in matrix (below): (D) microfossil spindle and filaments little deformed by neomorphic quartz crystals. All from Condon Collection of the Museum of Natural and Cultural History of the University of Oregon specimen F18310B=R4336 from A horizon of Jurnpa clay loam.

Fig. 8. Petrography of paleosols of the Farrel Quartzite, Western Australia, all the same view with crossed nicols to left and plane light to right: (A-B) late quartz vein with alteration halo in fossiliferous chert; (C-D) nahcolite sand crystals with many (above right) and few (below left) mineral inclusions; (E-F) barite sand crystal (center). Thin sections in the Condon Collection of the Museum of Natural and Cultural History of the University of Oregon are (A-B) R4336 from A horizon of Jurnpa clay loam, (C-D) R4334 from un-named Kari paleosol, (E-F) R4338 from By horizon of Jurnpa paleosol. 
Fig. 9. Petrography of paleosols (A-B) versus sediments (C-E) of the Farrel Quartzite, Western Australia: (A) massive fossiliferous and pyritic chert of A horizon of weakly developed paleosol; (B) crudely layered fossiliferous and pyritic chert of very weakly developed paleosol; (C) crudely bedded crystal lithic tuff with biotite and feldspar pseudomorphs (oxidation in from modern outcrop): (D) varved siltstone disrupted by syndepositional cracking; (E) five successive varves fining upwards from siltstone to neomorphic cherty shale. Thin sections in the Condon Collection of the Museum of Natural and Cultural History of the University of Oregon are (A) R4336 A horizon of Jurnpa clay loam; (B) R4346 A horizon of Ngumpu silty clay loam, (C) R4339 tuff above Ngumpu silty clay loam; (D) sandstone above Jurl clay loam; (E) shale below Jurl clay loam.

Fig. 10. Petrography of evaporite sand-crystal pseudomorphs in paleosols of the Farrel Quartzite, Western Australia: (A) spherulite of distinctive small crystals; (B-D) degraded rhomboids and nodules of barite (BaSO4); (E) pseudohexagonal laths of nahcolite $\left(\mathrm{NaHCO}_{3}\right)$ cutting bedding without deforming displacement. Thin sections in the Condon Collection of the Museum of Natural and Cultural History of the University of Oregon are (A) R4343 from By horizon of Kari silty clay loam; (B) R4351 from By horizon of Jurl clay loam; (C-D) R4344 from By horizon of Kari silty clay; (E) R4341 from By horizon of un-named Kari paleosol. Identification of nahcolite and barite is based on crystallographic and microprobe studies of Sugitani et al. (2003). 
Fig. 11. Mass balance geochemistry of Archean paleosols from Western Australia: (A)

deviation of paleosol samples (mole fraction) from parent material composition (at cross hairs) due to changes in volume (strain or epsilon) and changes in amounts of constituents (mass transfer or tau of Brimhall et al., 1992): (B) deviation of amounts of constituents (mass transfer or tau) with depth in paleosols. Most samples fall in paleosol field, but two surface samples of the Jurnpa paleosol show off-scale enrichment attributed to early silicification comparable with that found in the Devonian Rhynie Chert (Rice et al., 1995), thus accounting for extraordinary microfossil preservation in that horizon

(Sugitani et al., 2007, 2011).

Fig. 12. Reconstructed soils and microbes of the 3.0 Ga Farrel Quartzite, Western Australia.

Table 1. Summary of Farrel Quartzite paleosol definition and classification

\begin{tabular}{|c|c|c|c|c|c|}
\hline Pedotype & $\begin{array}{l}\text { Nyamal } \\
(52)\end{array}$ & Diagnosis & $\begin{array}{l}\text { US taxo- } \\
\text { nomy }\end{array}$ & $\begin{array}{l}\text { FAO map } \\
\text { unit }\end{array}$ & $\begin{array}{l}\text { Australian } \\
\text { Classification }\end{array}$ \\
\hline Jurnpa & Cold ashes & $\begin{array}{l}\text { Black massive cherty surface (A horizon) over gypsum } \\
\text { mottle pseudomorphs in trough cross-bedded } \\
\text { sandstone (By horizon) }\end{array}$ & Ustept & $\begin{array}{l}\text { Eutric } \\
\text { Cambisol }\end{array}$ & $\begin{array}{l}\text { Grey-orthic } \\
\text { Tenosol }\end{array}$ \\
\hline Jurl & Salt & $\begin{array}{l}\text { Black massive cherty surface (A horizon) over gypsum } \\
\text { crystal pseudomorphs in grey chert (By horizon) }\end{array}$ & Cambid & $\begin{array}{l}\text { Orthic } \\
\text { Solonchak }\end{array}$ & Grey Sodosol \\
\hline Kari & Bitter salt & $\begin{array}{l}\text { Black massive cherty surface (A horizon) over gypsum } \\
\text { crystal fan pseudomorphs in grey chert (By horizon) }\end{array}$ & Cambid & $\begin{array}{l}\text { Orthic } \\
\text { Solonchak }\end{array}$ & Grey Sodosol \\
\hline Ngumpu & Narrow & $\begin{array}{l}\text { Black massive cherty surface ( } A \text { horizon) over } \\
\text { laminated grey chert ( } \mathrm{C} \text { horizon). }\end{array}$ & Fluvent & $\begin{array}{l}\text { Eutric } \\
\text { Fluvisol }\end{array}$ & Stratic Rudosol \\
\hline
\end{tabular}

Table 2. Summary of Farrel Quartzite paleosol interpretations

\begin{tabular}{|c|c|c|c|c|c|}
\hline Pedotype & Climate & Organisms & Topography & Parent material & Soil duration \\
\hline Jurnpa & $\begin{array}{l}\text { Humid }(1112 \pm 182 \mathrm{~mm} \text { MAP }) \\
\text { temperate }\left(8.3 \pm 0.4^{\circ} \mathrm{C} \text { MAT }\right)\end{array}$ & $\begin{array}{l}\text { Microbial earth dominated by } \\
\text { methanogens and actinobacteria, with } \\
\text { purple sulfur bacteria }\end{array}$ & $\begin{array}{l}\text { Streamside } \\
\text { levee }\end{array}$ & $\begin{array}{l}\text { Quartz-lithic } \\
\text { sand }\end{array}$ & $\begin{array}{l}1,000-69,000 \\
\text { years }\end{array}$ \\
\hline Jurl & $\begin{array}{l}\text { Humid ( } 1443 \pm 182 \mathrm{~mm} \text { MAP }) \\
\text { temperate }\left(11.1 \pm 0.4^{\circ} \mathrm{C} \text { MAT) }\right.\end{array}$ & $\begin{array}{l}\text { Microbial earth dominated by purple } \\
\text { sulfur bacteria, with actinobacteria and } \\
\text { methanogens }\end{array}$ & Floodplain & Quartz-lithic silt & $\begin{array}{l}2,000-82,000 \\
\text { years }\end{array}$ \\
\hline Kari & $\begin{array}{l}\text { Humid }(1319 \pm 182 \mathrm{~mm} \text { MAP }) \\
\text { temperate }\left(10.1 \pm 0.4^{\circ} \mathrm{C} \text { MAT }\right)\end{array}$ & $\begin{array}{l}\text { Microbial earth dominated by purple } \\
\text { sulfur bacteria and methogens, with } \\
\text { actinobacteria }\end{array}$ & Floodplain & Quartz-lithic silt & $\begin{array}{l}6,000- \\
116,000 \\
\text { years }\end{array}$ \\
\hline Ngumpu & Not diagnostic for climate & $\begin{array}{l}\text { Microbial earth dominated by } \\
\text { methanogens and actinobacteria, with } \\
\text { purple sulfur bacteria }\end{array}$ & $\begin{array}{l}\text { Streamside } \\
\text { bar }\end{array}$ & $\begin{array}{l}\text { Quartz-lithic } \\
\text { sand }\end{array}$ & $\begin{array}{l}10-1000 \\
\text { years }\end{array}$ \\
\hline
\end{tabular}


Note: MAP is mean annual precipitation and MAT is mean annual temperature.

\section{Table 3. Microfossils of the 3.0 Ga Farrel Quartzite}

\begin{tabular}{|c|c|c|c|c|}
\hline Morphotype (9) & $\begin{array}{l}\text { Precambrian } \\
\text { microfossil form } \\
\text { taxonomy }\end{array}$ & $\begin{array}{l}\text { Carbon isotopic } \\
\text { composition } \\
\left(\delta^{13} C_{P D B}\right)\end{array}$ & $\begin{array}{l}\text { Plausible taxonomic } \\
\text { affinities }\end{array}$ & Inferred metabolism \\
\hline Thread & $\begin{array}{l}\text { Archaeotrichon } \\
\text { contortum }\end{array}$ & $\begin{array}{l}-35.2 \pm 1.0 \\
(-34.4 \text { to }-36.3, n=3)\end{array}$ & Actinobacteria & Anaerobic fermentation \\
\hline $\begin{array}{l}\text { Simple wall } \\
\text { spheroid }(10- \\
60 \mu \mathrm{m})\end{array}$ & Archaeosphaeroides sp. & $-28.7, n=1$ & $\begin{array}{l}\text { Chromatiaceae (purple } \\
\text { sulfur bacteria) }\end{array}$ & $\begin{array}{l}\text { Anaerobic } \\
\text { photosynthesis }\end{array}$ \\
\hline $\begin{array}{l}\text { Diffuse wall } \\
\text { spheroid }(20- \\
40 \mu \mathrm{m})\end{array}$ & $\begin{array}{l}\text { Archaeosphaeroides } \\
\text { pilbarensis }\end{array}$ & $\begin{array}{l}-36.5 \pm 2.3 \\
(-34.3 t \quad-38.6, n=4)\end{array}$ & $\begin{array}{l}\text { Chromatiaceae (purple } \\
\text { sulfur bacteria) }\end{array}$ & $\begin{array}{l}\text { Anaerobic } \\
\text { photosynthesis }\end{array}$ \\
\hline $\begin{array}{l}\text { Thick wall } \\
\text { spheroid ( } 30 \text { - } \\
40 \mu \mathrm{m})\end{array}$ & $\begin{array}{l}\text { Archaeosphaeroides } \\
\text { sp. }\end{array}$ & Not analyzed & $\begin{array}{l}\text { Chromatiaceae (purple } \\
\text { sulfur bacteria) with } \\
\text { sulfur globules) }\end{array}$ & $\begin{array}{l}\text { Anaerobic } \\
\text { photosynthesis }\end{array}$ \\
\hline $\begin{array}{l}\text { Folded wall } \\
\text { spheroid }(20- \\
40 \mu \mathrm{m})\end{array}$ & Archaeosphaeroides sp. & $\begin{array}{l}-34.1 \pm 0.1 \\
(-34.0 \text { to }-34.1, n=2)\end{array}$ & $\begin{array}{l}\text { Chromatiaceae (purple } \\
\text { sulfur bacteria) with } \\
\text { sulfur globules) }\end{array}$ & $\begin{array}{l}\text { Anaerobic } \\
\text { photosynthesis }\end{array}$ \\
\hline $\begin{array}{l}\text { Small }(<15 \\
\mu \mathrm{m}) \text { spheroid }\end{array}$ & $\begin{array}{l}\text { Archaeosphaeroides } \\
\text { barbertonensis }\end{array}$ & $\begin{array}{l}-37.9 \pm 3.3 \\
(-33.8 \text { to }-44.2 \\
n=13)\end{array}$ & $\begin{array}{l}\text { Methanosarcinaceae }(\mathrm{A} \\
\text { rchaea) }\end{array}$ & Methanogenesis \\
\hline $\begin{array}{l}\text { Thick } \\
\text { laminated film }\end{array}$ & "Eoclathrus" sp. & $\begin{array}{l}-31.5 \pm 4,0 \\
(-26.0 \text { to }-40.3 \\
n=13)\end{array}$ & $\begin{array}{l}\text { Mixed microbial mat } \\
\text { fragment }\end{array}$ & $\begin{array}{l}\text { Mixed anaerobic } \\
\text { microbial mat }\end{array}$ \\
\hline $\begin{array}{l}\text { Spindle }(10-90 \\
\mu \mathrm{m})\end{array}$ & cf. Eupoikilofusa sp. & $\begin{array}{l}-36.9 \pm 1.7 \\
(-35.6 \text { to }-40.5, n=8)\end{array}$ & Actinobacteria & $\begin{array}{l}\text { Anaerobic } \\
\text { Fermentation }\end{array}$ \\
\hline
\end{tabular}



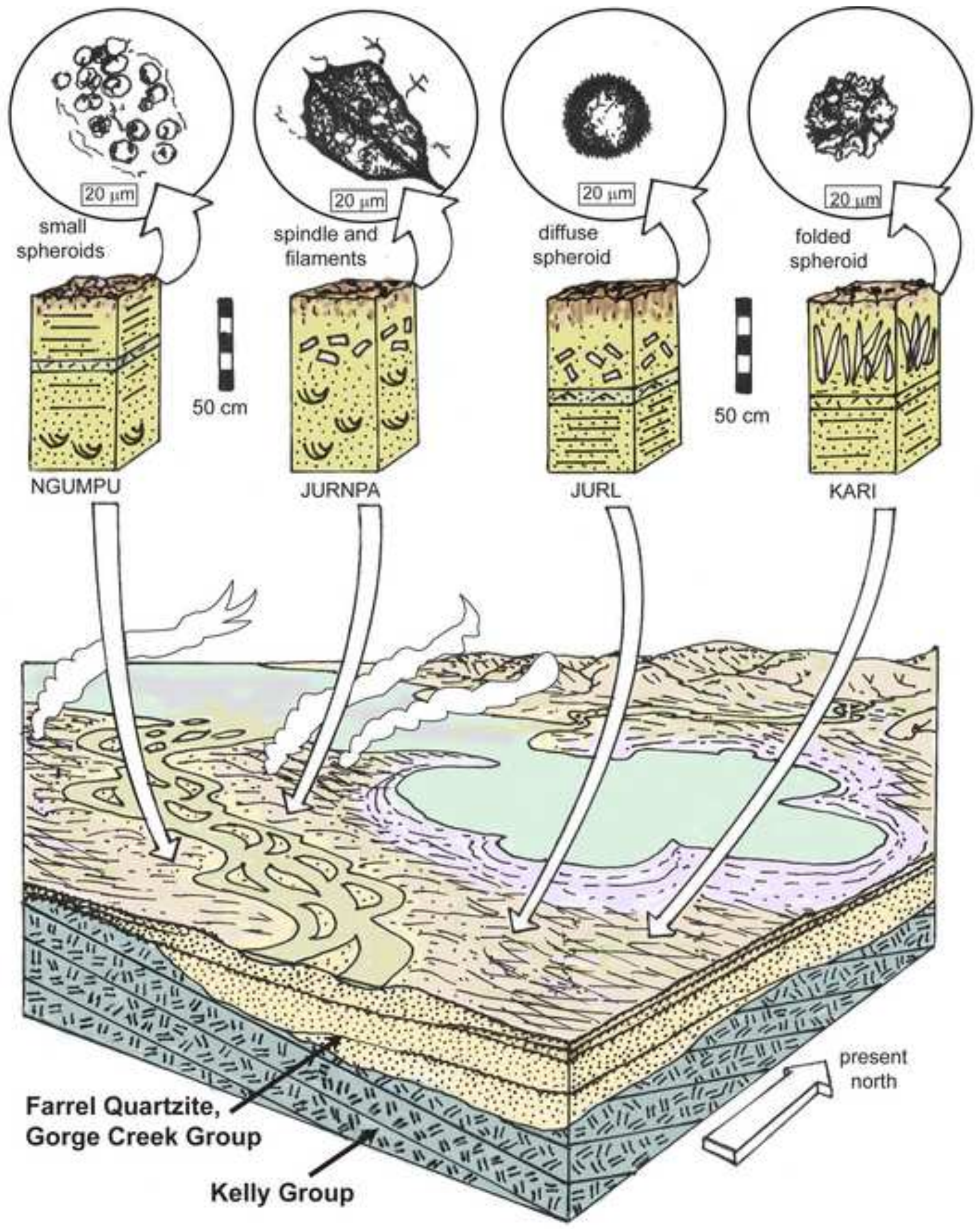


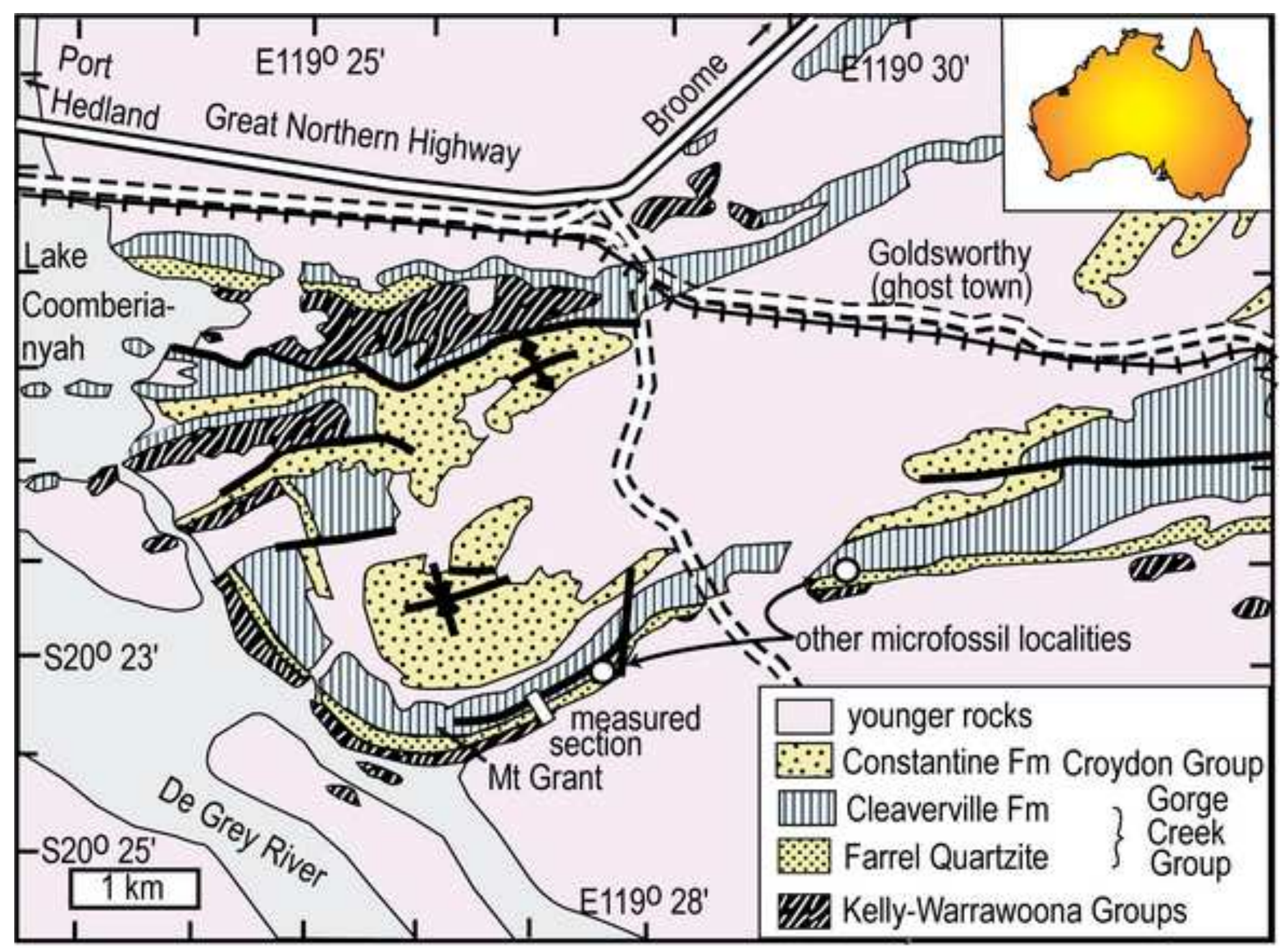

Retallack et al. Fig. 1 

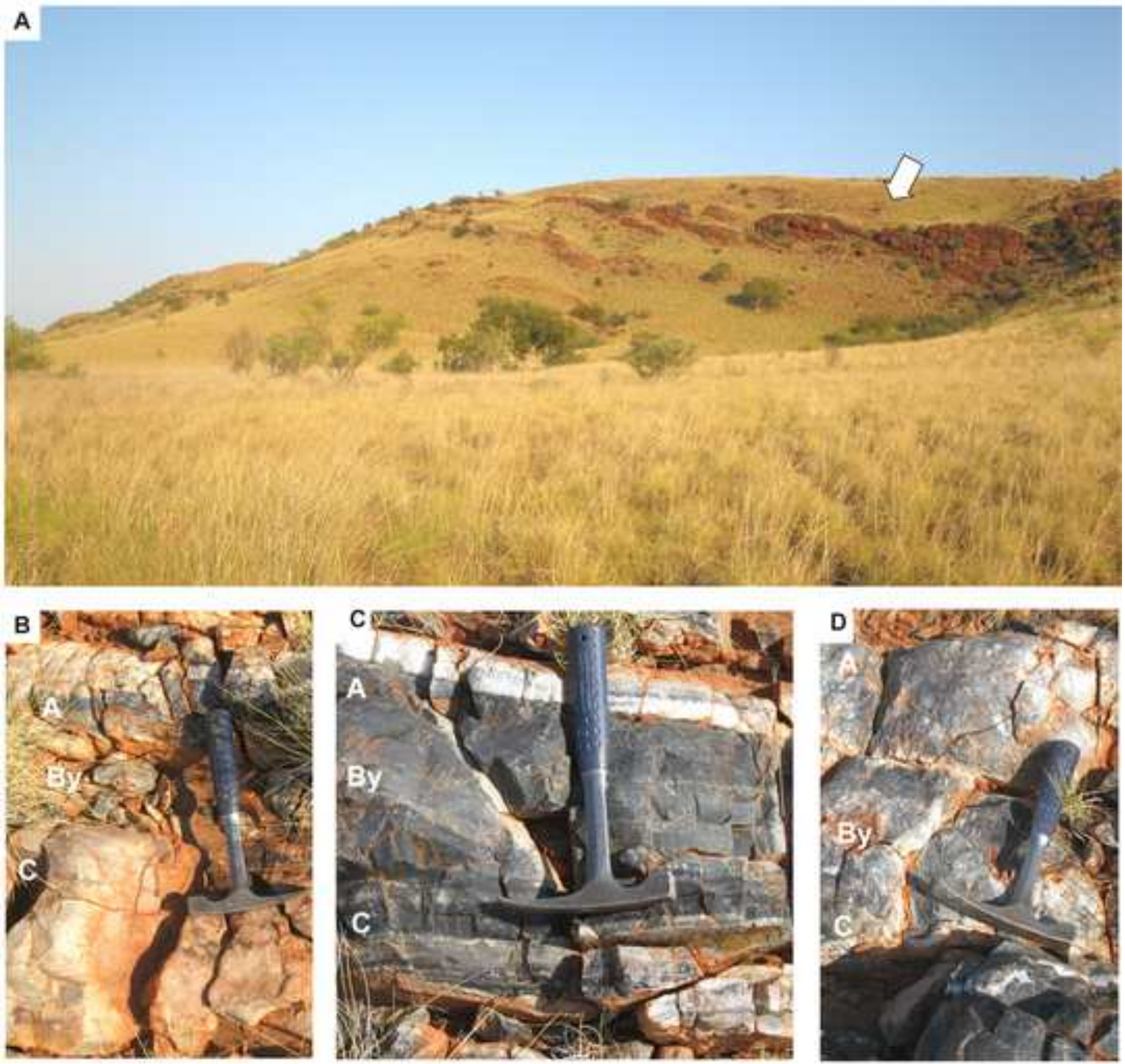

Retallack et al. Fig. 2 


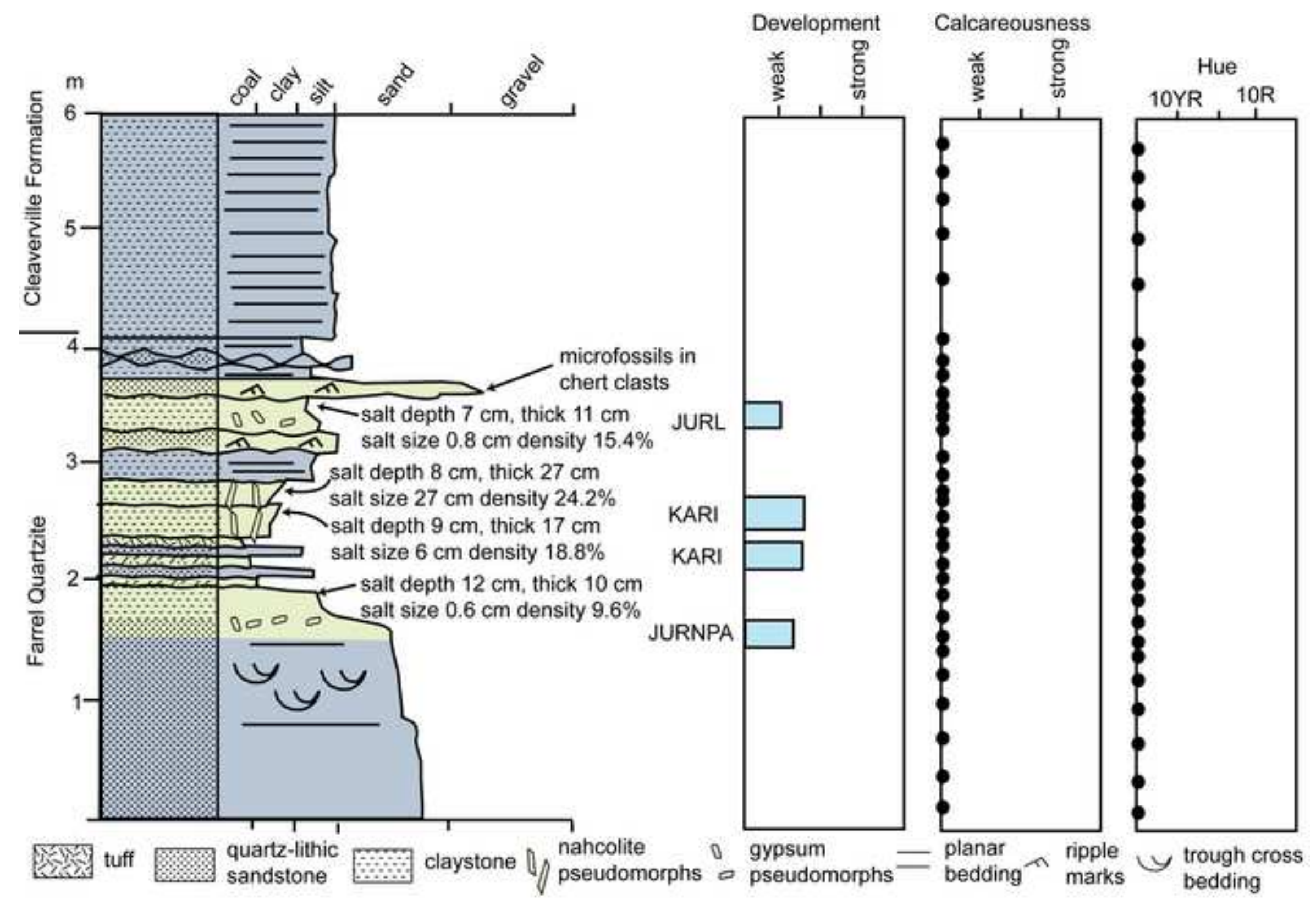

Retallack et al., Fig. 3 

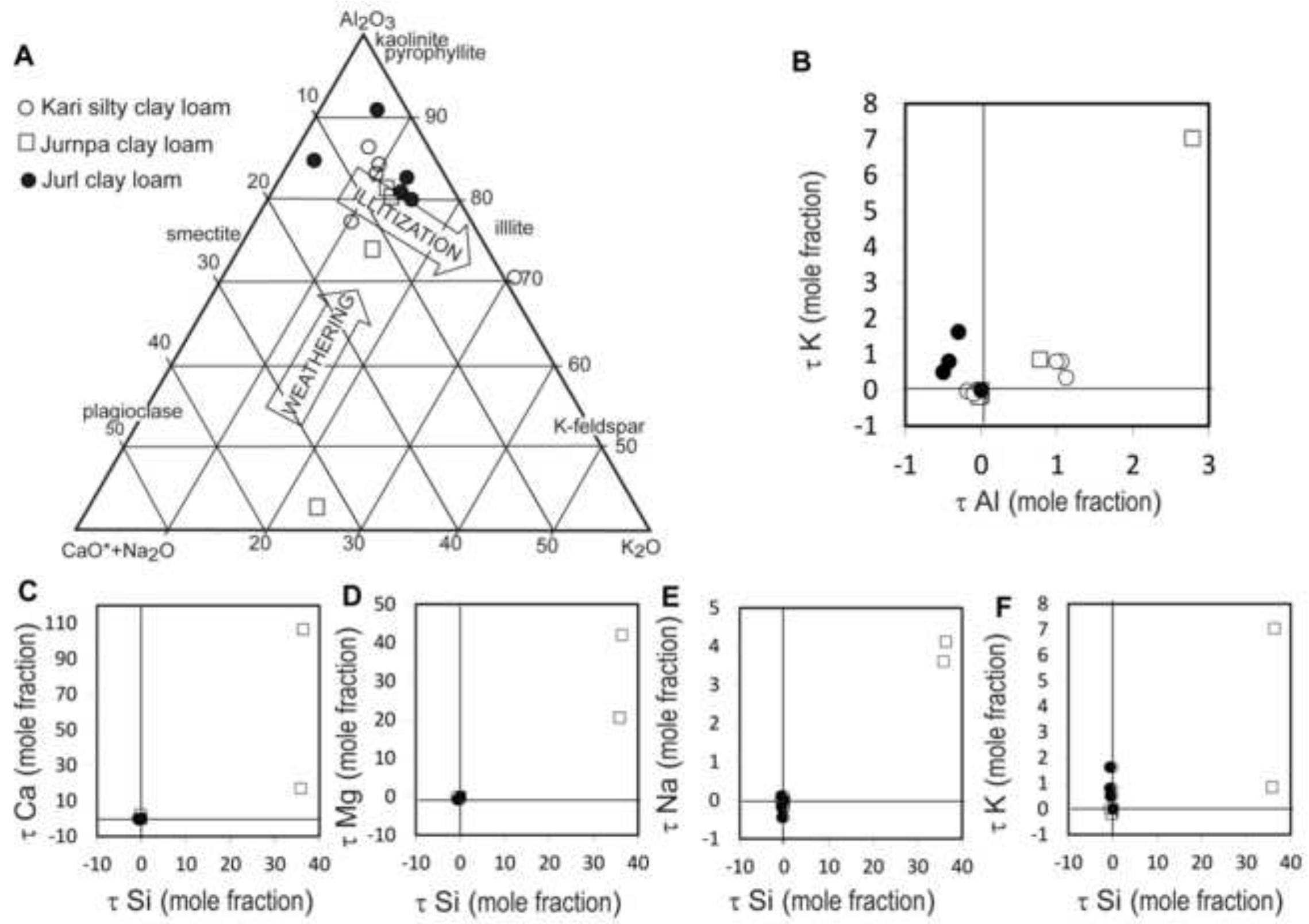

Retallack et al. Fig. 4 

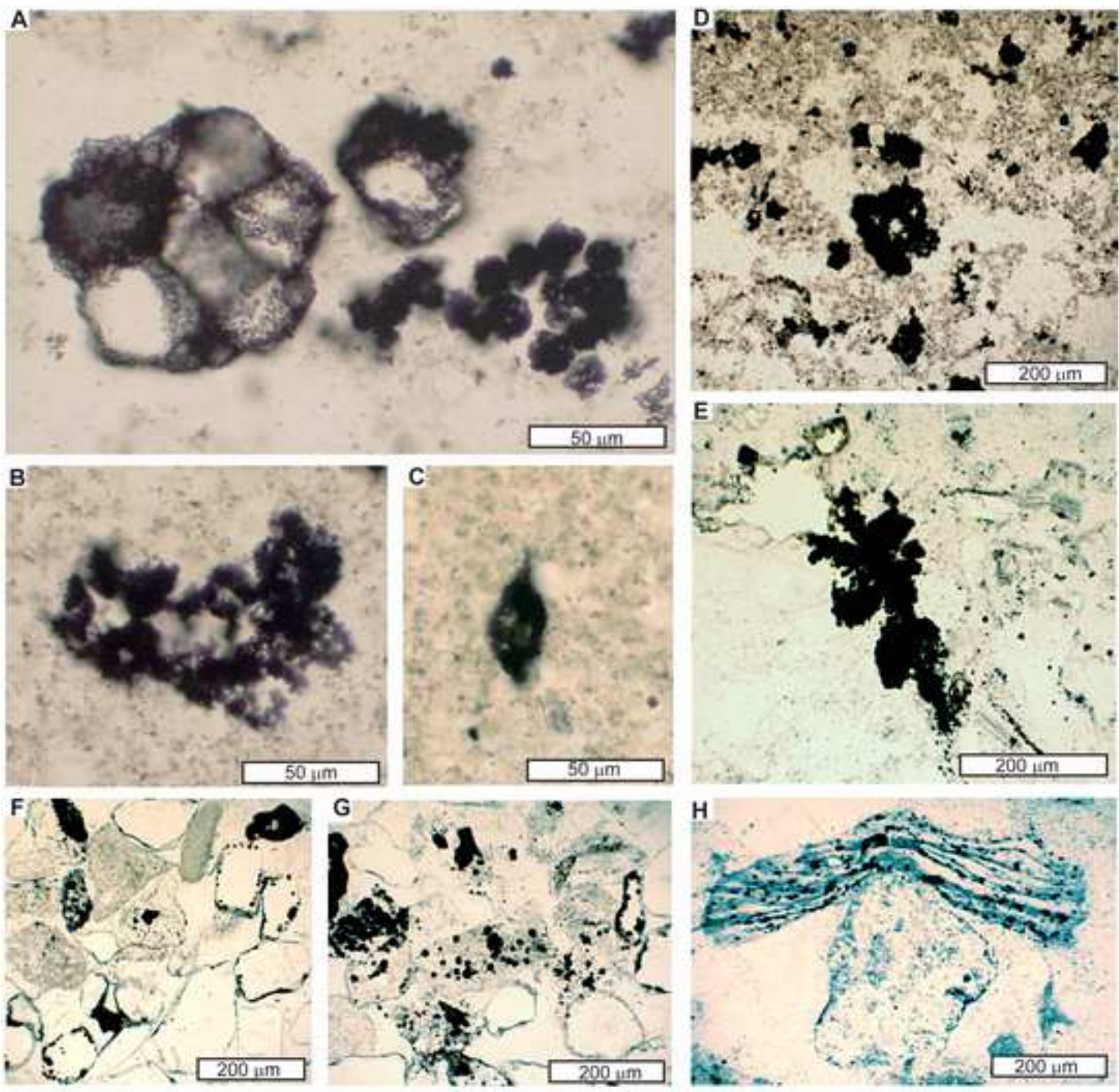

Retallack et al. Fig. 5 


\section{a. Field observations}

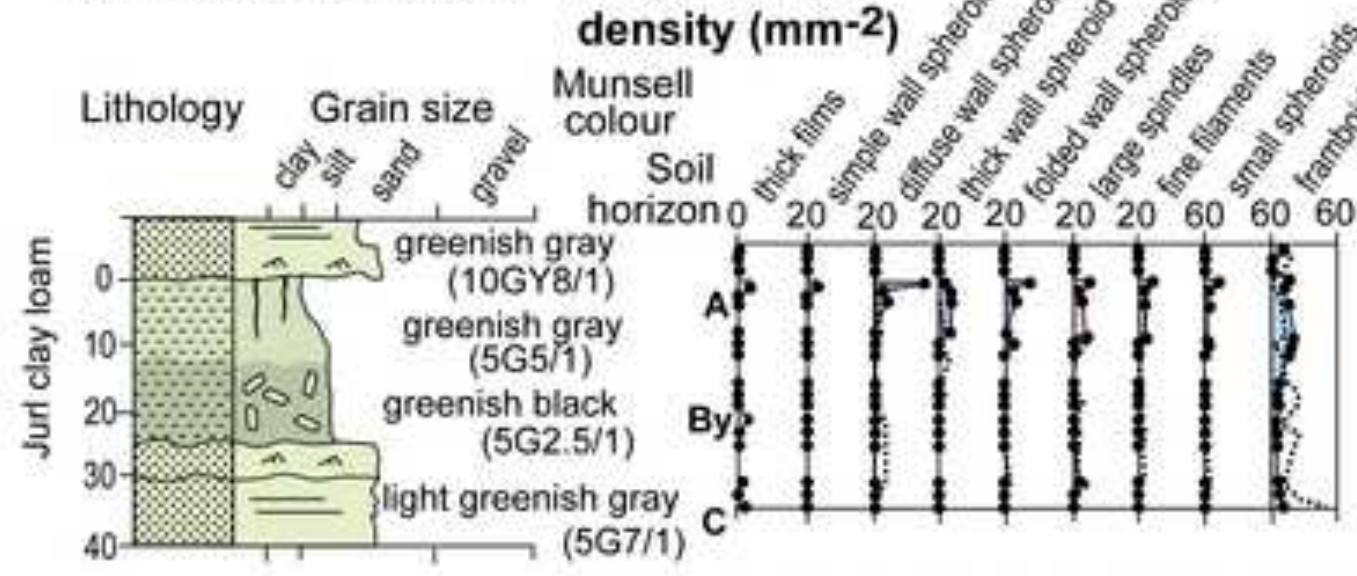

c. Point counting

$(\%)$

\section{Grain} size Minerals

\section{d. Molecular weathering ratios (mole/mole)}

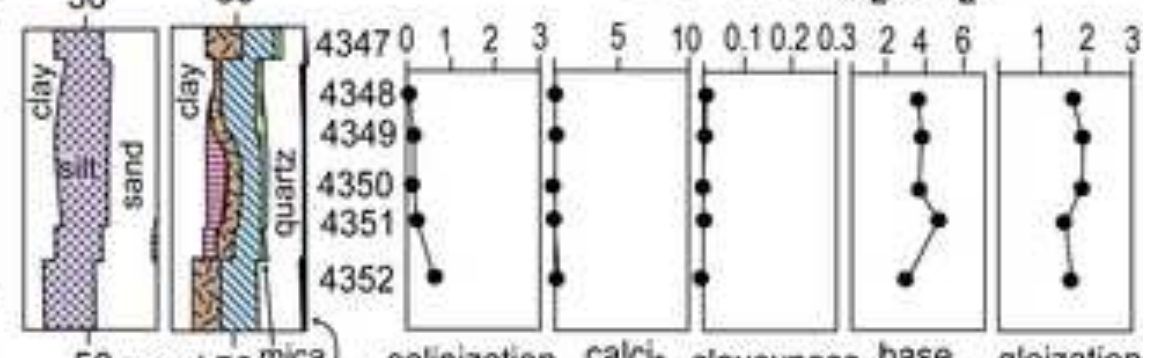

50 gravel 50 mica salinization calci- clayeyness base
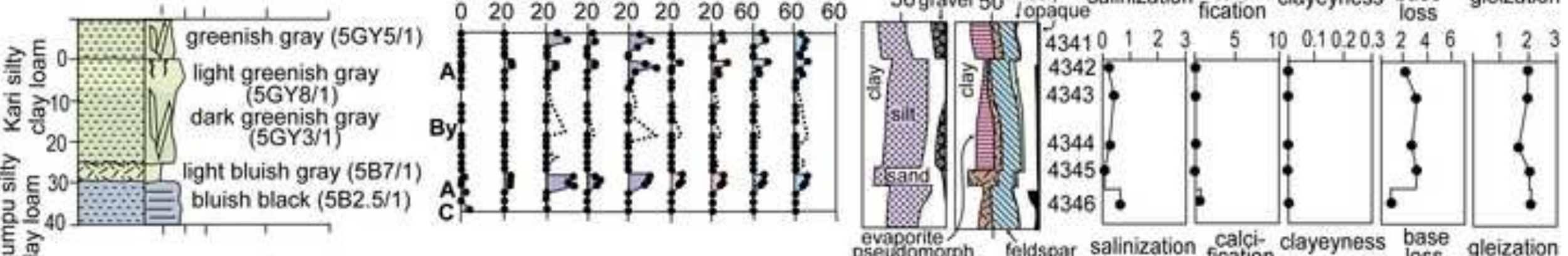

营恶

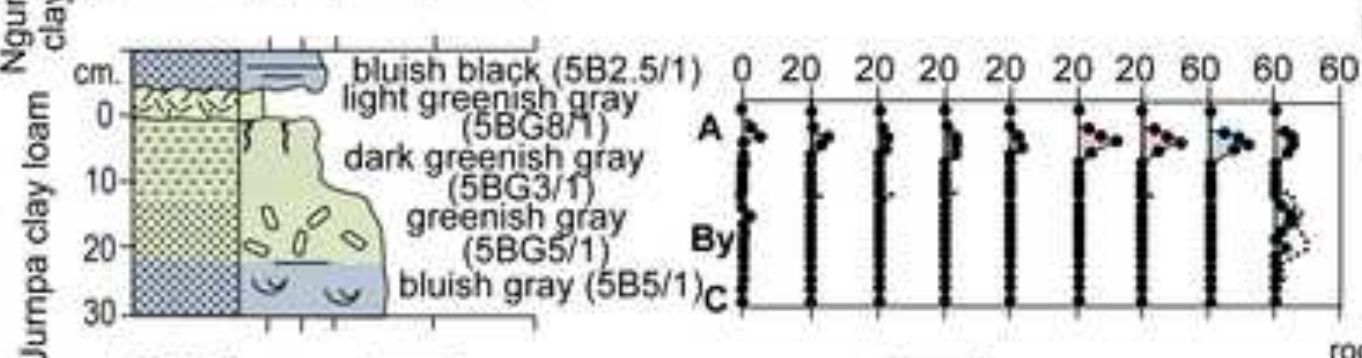

致济 tuff

w........ quartz-lithic sandstone

I I iron-manganese veins

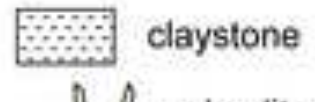

If I nahcolite pseudomorphs pseugomorph 50 teldspar salinization fication clayeyness loss gleization

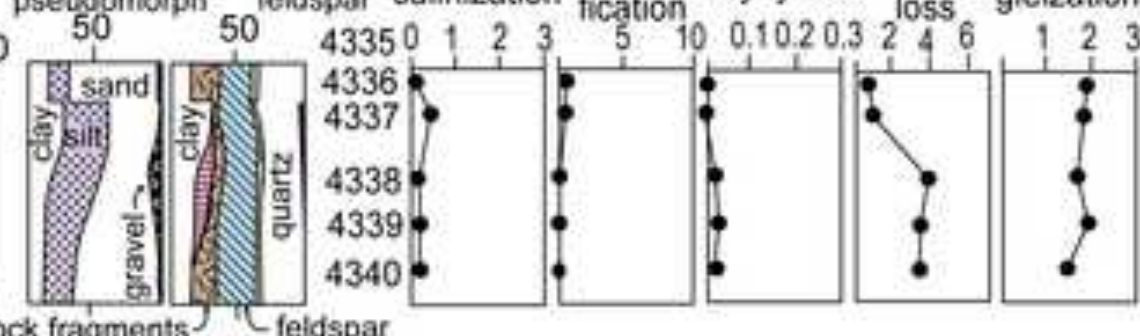

ckeldspar

- planar bedding ${ }_{A}$ ripple marks $\aleph_{y}$ trough cross bedding teldspar

O barite pseudomorphs

Retallack et al. Fig. 6 


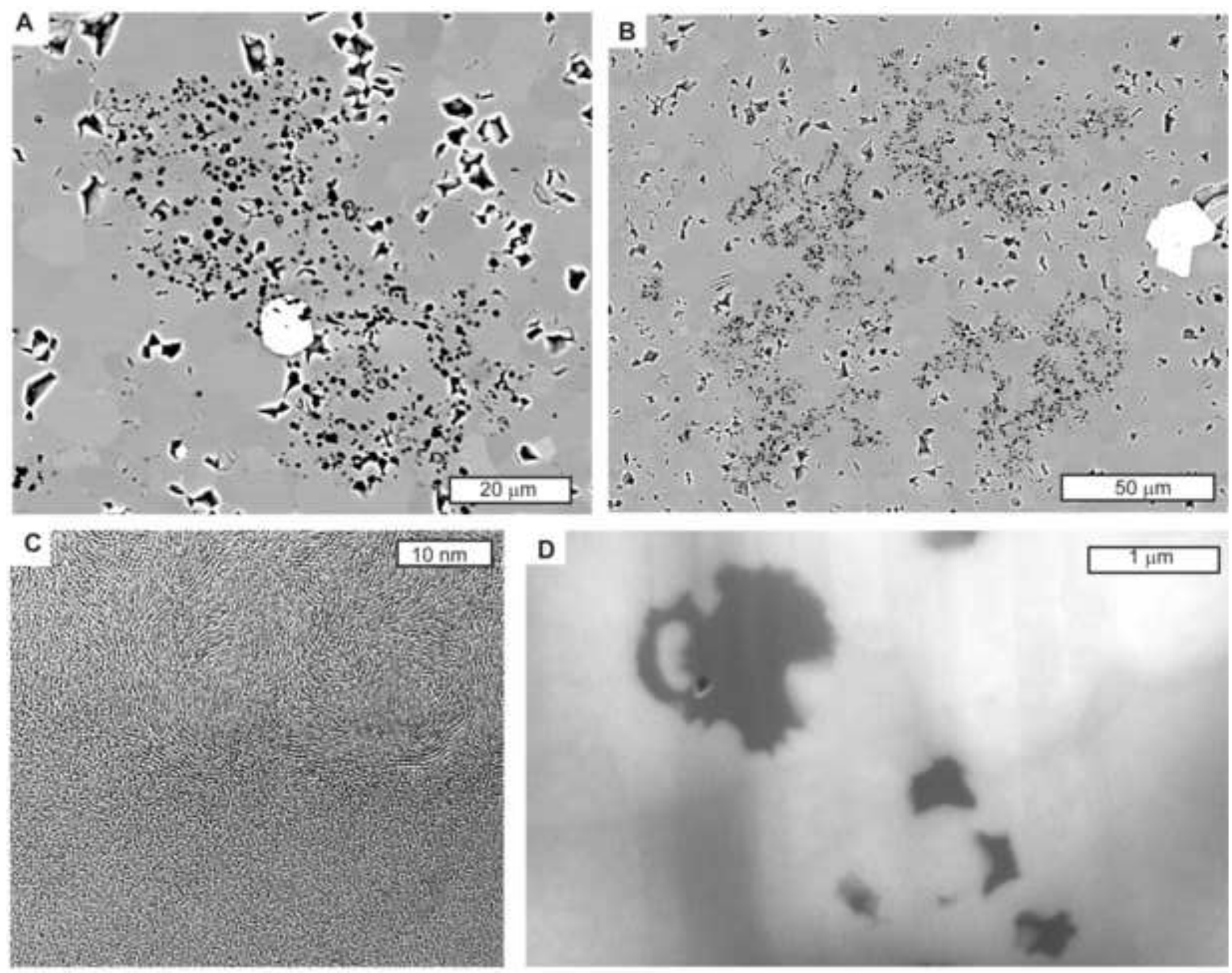

Retallack et al. Fig. 7 

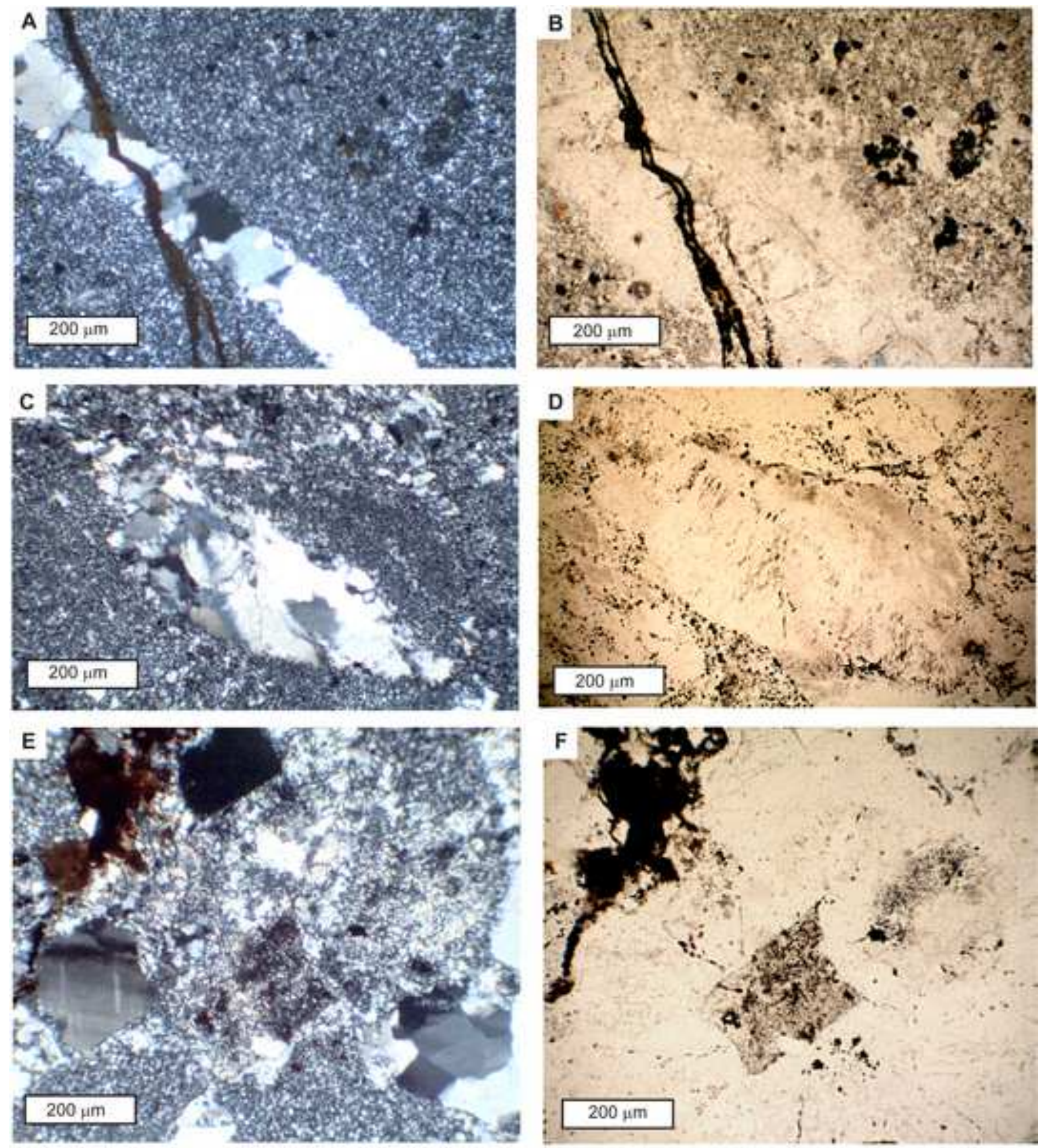

Retallack et al., Fig. 8 

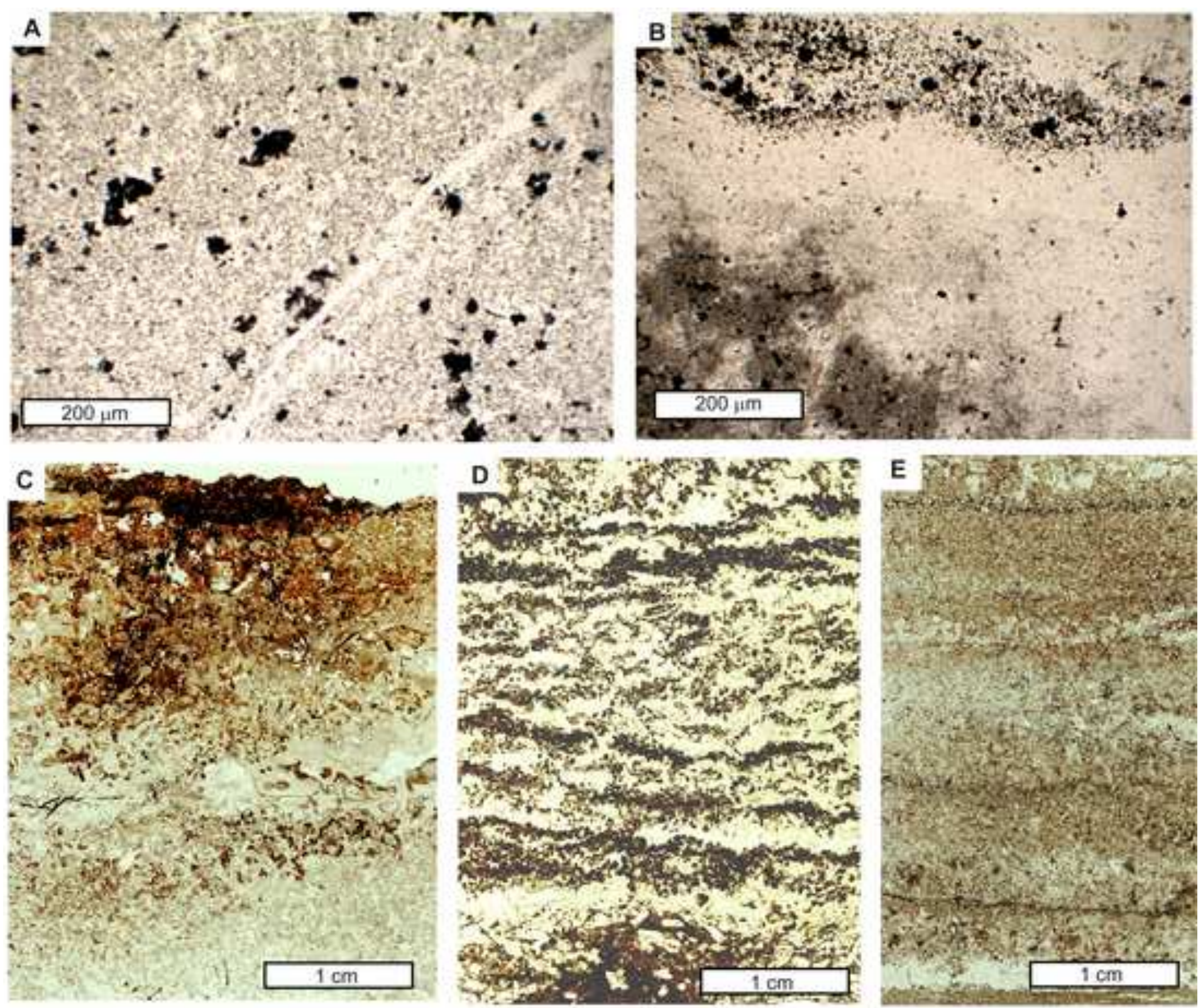

Retallack et al., Fig. 9 

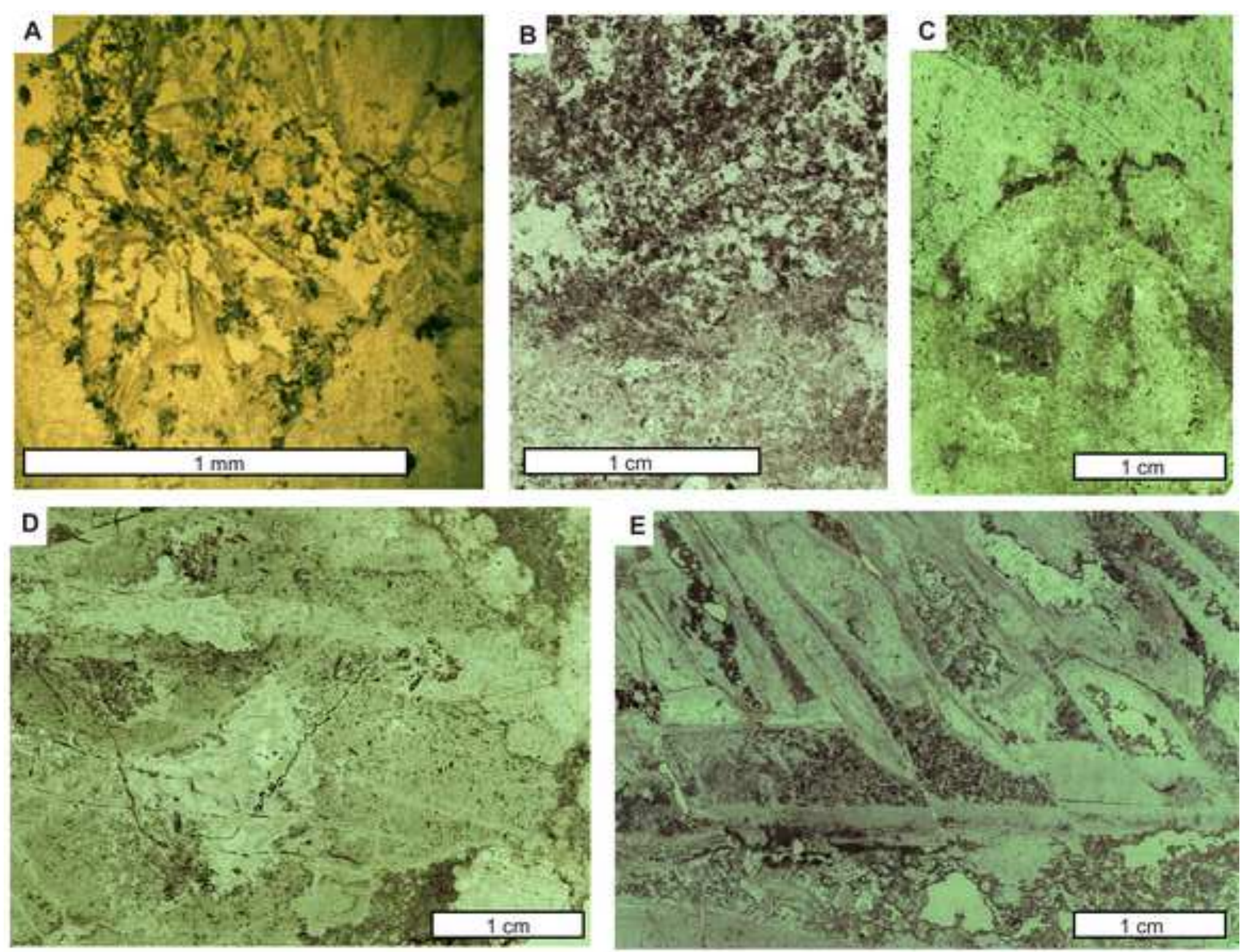

Retallack et al., Fig. 10 
a. mass transfer with strain
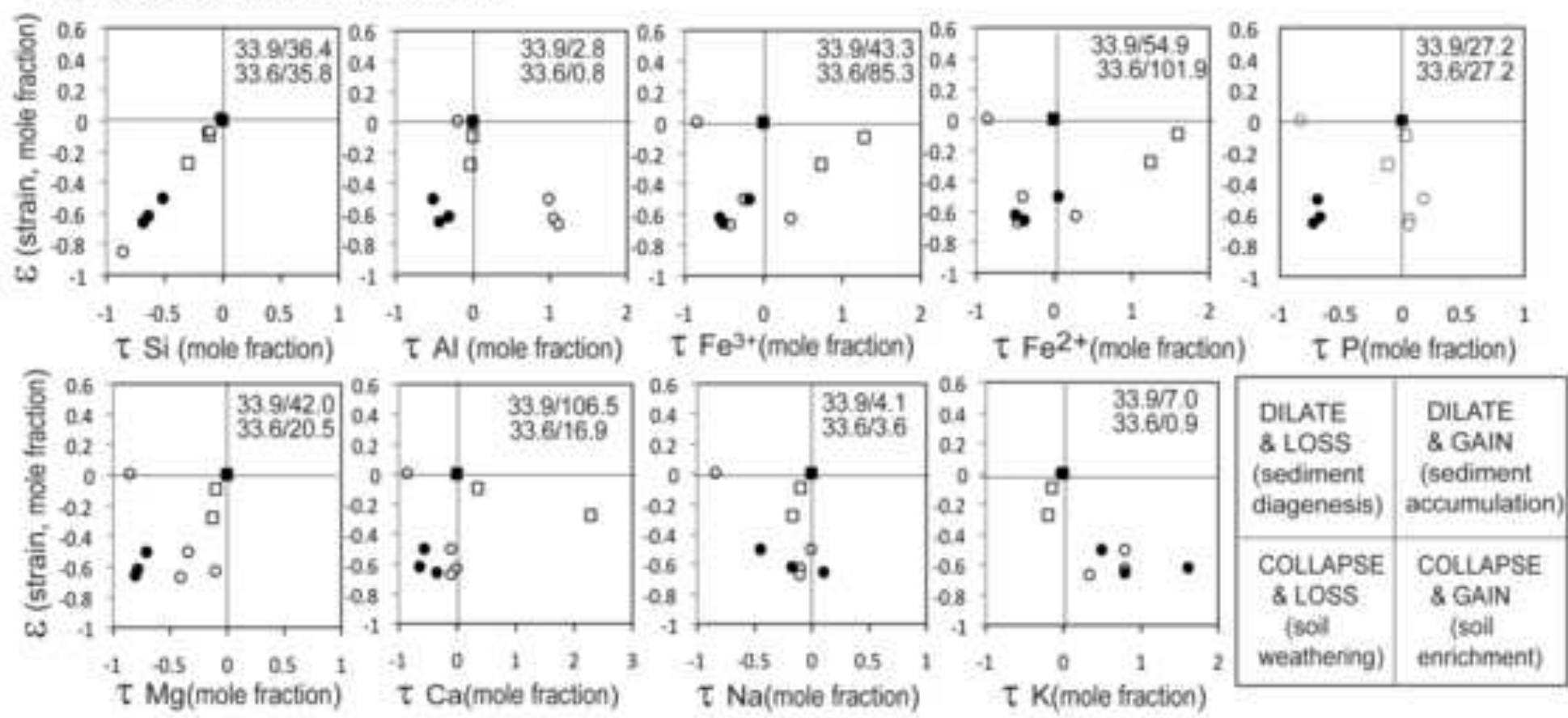

b. mass transfer with depth

KEY • type Juri silty clay o type Kari silty clay

$\square$ type Jumpa clay

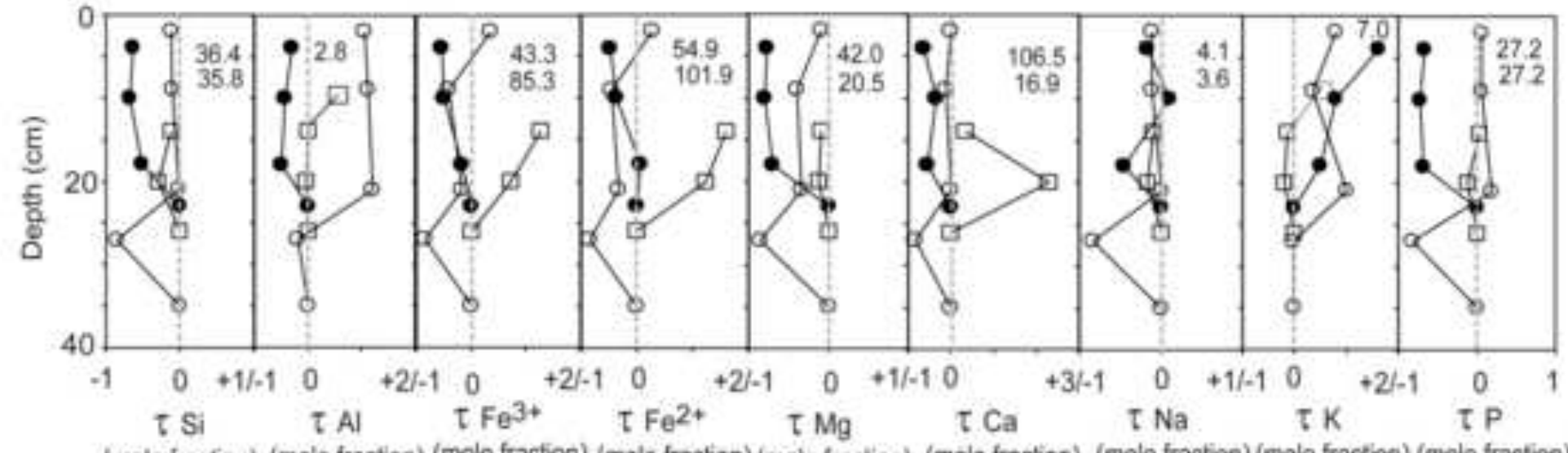

(mole fraction) (mole fraction) (mole fraction) (mole fraction) (mole fraction) (mole fraction) (mole fraction) (mole fraction) (mole fraction) 


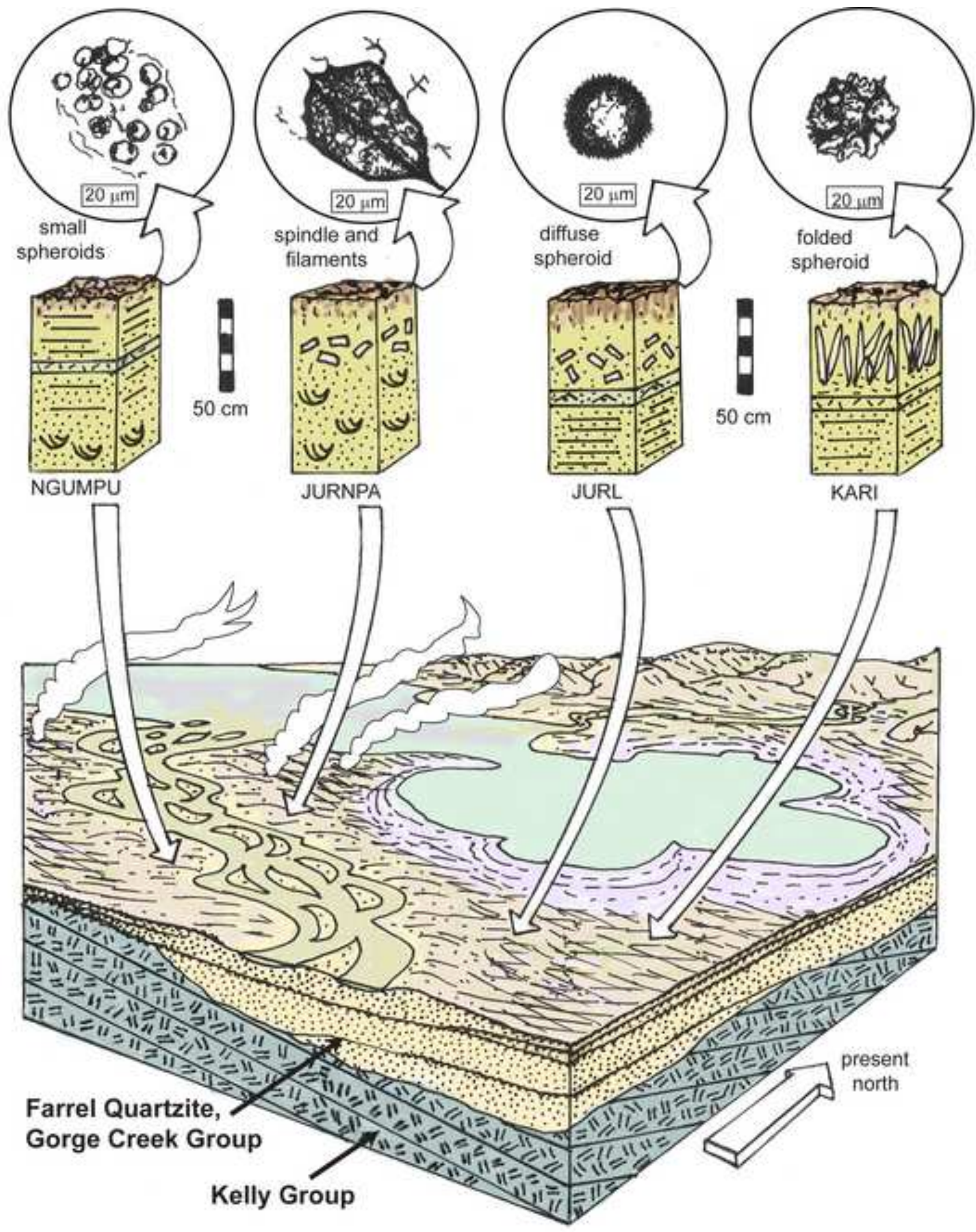

